Distribution DE92 001055

\title{
FEASIBILITY STUDY OF HEAVY OIL RECOVERY IN THE APPALACHIAN, BLACK WARRIOR, ILLINOIS, AND MICHIGAN BASINS
}

\author{
By \\ D. K. Olsen \\ V. Rawn-Schatzinger \\ E. B. Ramzel
}

July 1992

Work Performed Under Cooperative Agreement No. DE-FC22-83FE60149

Prepared for

U.S. Department of Energy

Assistant Secretary for Fossil Energy

Thomas B. Reid, Project Manager

Bartlesville Project Office

P. O. Box 1398

Bartlesville, OK 74005

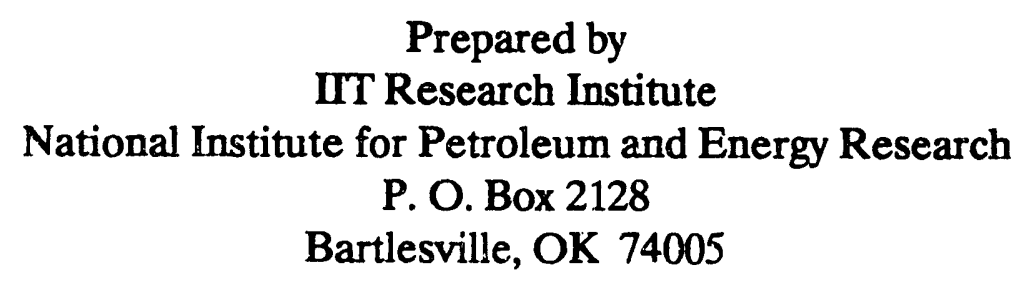




\section{TABLE OF CONTENTS}

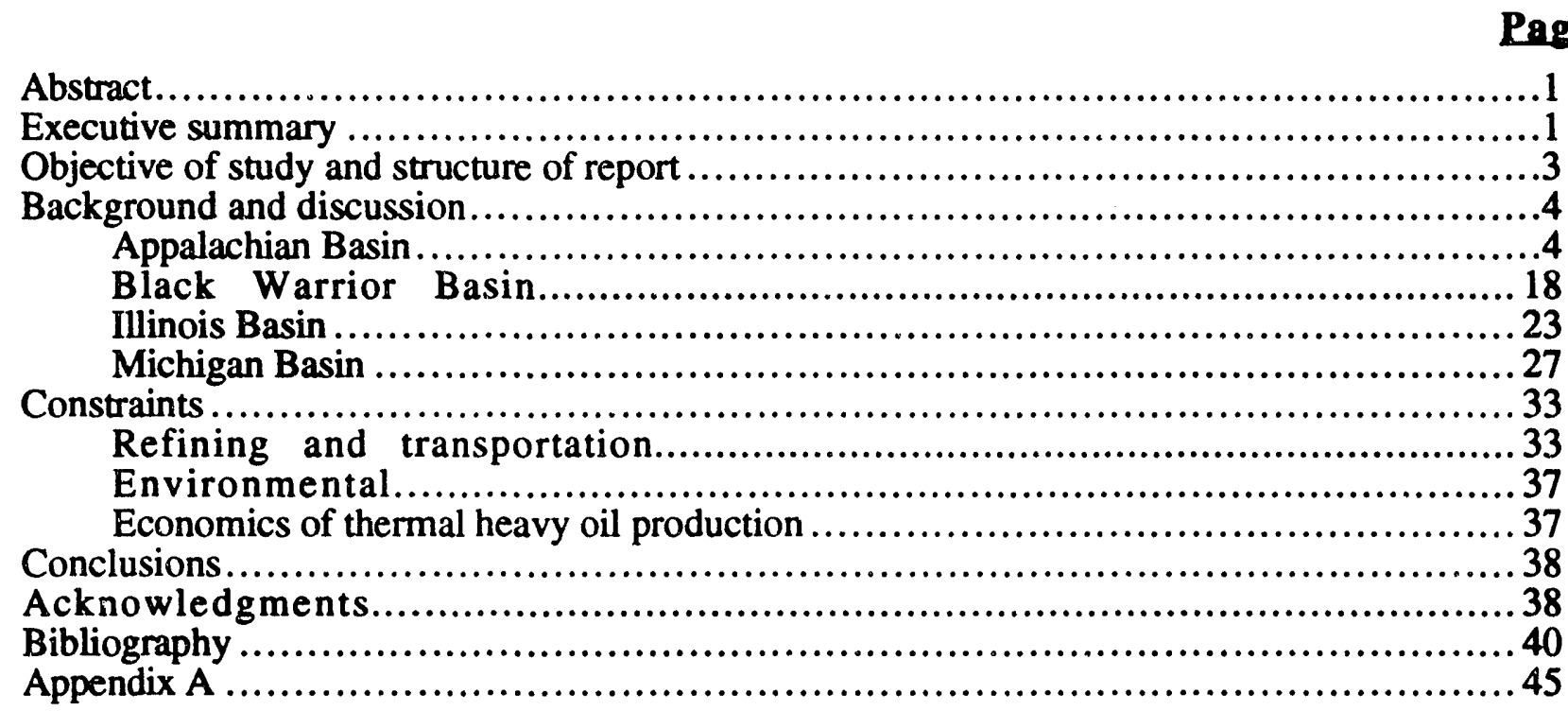

\section{TABLES}

1. Cost of drilling and completing thermal EOR wells ................................38

2. Yearly thermal steam operating-cost ranges within each field/well ...................38

3. Comparisons of economic factors affecting oil production from middle U.S............ 39

A-1. Appalachian, Black Warrior, Illinois and Michigan Heavy Oil Reservoirs...............45

\section{ILLUSTRATIONS}

1. Map of the United States showing the major depositional basins and their regional

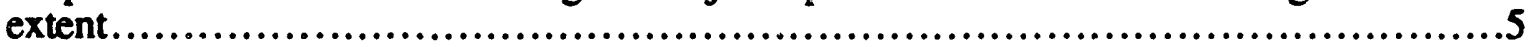

2. The sedimentary basins of the Eastern United States ...........................................6

3. The Appalachian Basin showing the relationship of hydrocarbon producing areas to

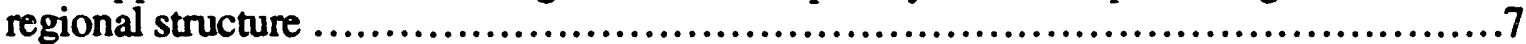

4. The distribution of Upper Paleozoic sedimentary rocks and structural relationships for the central Appalachian Basin ...................................................8

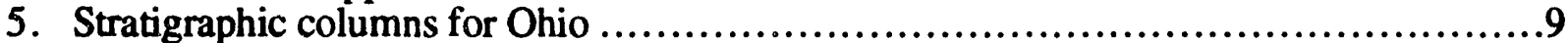

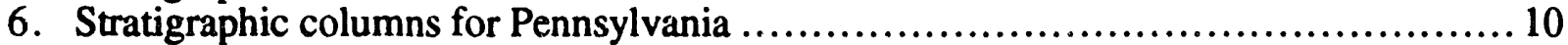

7. Stratigraphic columns for New York......................................................11

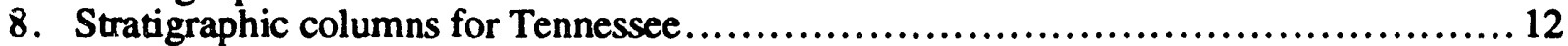

9. Stratigraphic columns for Kentucky............................................................... 13

10. Stratigraphic columns for West Virginia ........................................ 14

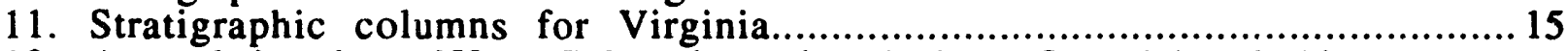

12. A correlation chart of Upper Paleozoic stratigraphy in the Central Appalachian Basin 


\section{ILLUSTRATIONS-Continued}

13. Black Warrior Basin of Alabama and Mississippi showing oil and gas fields as

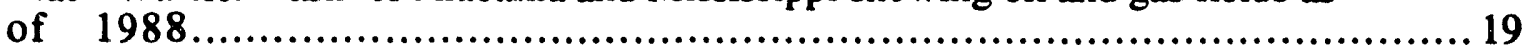

14. Maps of the Black Warrior Basin showing the regional structural features.................. 20

15. Stratigraphic column of the Black Warrior Basin showing oil and gas producing areas.

16. A structure map of the Alabama portion of the Black Warrior Basin showing the complicated fault system which traps oil and gas................................. 22

17. The main part of the Illinois Basin showing the fault zones and oil and gas exploration in 1984

18. An east-to-west cross section of the Illinois Basin ...............................25

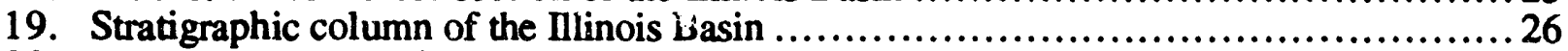

20. A structure map of the western two-thirds of the Illinois Basin...............................28

21. The Michigan Basin showing the distribution of Paleozoic rock units and the

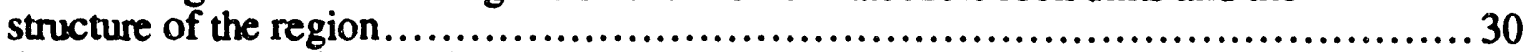

22. A structure map of the main portion of the Michigan Basin ...........................31

23. The stratigraphic column of the Michigan Basin showing the oil and gas reservoirs..... 32

24. Map of the crude oil pipeline system within the United States ........................ 34

25. Map of Petroleum Administration for Defense Districts and location of major oil refineries within the United States

26. Trends in API gravity of refinery feed within each PADD in the United States............36

27. Trends in sulfur content of refinery feed within each PADD in the United States....... 36 


\title{
FEASIBILITY STUDY OF HEAVY OIL RECOVERY IN THE APPALACHIAN, BLACK WARRIOR, ILLINOIS, AND MICHIGAN BASINS
}

\author{
By D. K. Olsen, V. Rawn-Schatzinger, and E. B. Ramzel
}

\begin{abstract}
This report is one of a series of publications assessing the feasibility of increasing domestic heavy oil production. Each report covers select areas of the United States. The Appalachian, Black Warrior, Illinois, and Michigan basins cover most of the depositional basins in the Midwest and Eastern United States. These basins produce sweet, paraffinic light oil and are considered minor heavy oil $\left(10^{\circ}\right.$ to $20^{\circ}$ API gravity or 100 to $10,000 \mathrm{cP}$ viscosity) producers. Heavy oil occurs in both carbonate and sandstone reservoirs of Paleozoic Age along the perimeters of the basins in the same sediments where light oil occurs. The oil is heavy because escape of light ends, water washing of the oil, and biodegradation of the oil have occurred over millions of years. The Appalachian, Black Warrior, Illinois, and Michigan basins' heavy oil fields have produced some $450,000 \mathrm{bbl}$ of heavy oil of an estimated $14,000,000 \mathrm{bbl}$ originally in place.

The basins have been long-term, major light-oil-producing areas and are served by an extensive pipeline network connected to refineries designed to process light sweet and with few exceptions limited volumes of sour or heavy crude oils. Since the light oil is principally paraffinic, it commands a higher price than the asphaltic heavy crude oils of California. The heavy oil that is refined in the Midwest and Eastern U.S. is imported and refined at select refineries. Imports of crude of all grades accounts for 37 to $>95 \%$ of the oil refined in these areas.

Because of the nature of the resource, the Appalachian, Black Warrior, nlinois and Michigan basins are not expected to become major heavy oil producing areas. The crude oil collection system will continue to degrade as light oil production declines. Smaller refineries will close due to lack of local, sweet light oil, economies of scale and environmental constraints on operations and product quality. Major refineries will refine increasing volumes of imported higher sulfur, lower gravity crude oil from Canada and Venezuela. Select East Coast refineries will process increasing volumes of light Mideast crude. The demand for crude oil will increase pipeline and tanker transport of imported crude to select large refineries to meet the areas' liquid fuels needs.
\end{abstract}

\section{EXECUTIVE SUMMARY}

This report is one of a series of publications assessing the feasibility of increasing domestic heavy oil production. Each report covers select areas of the United States. The Appalachian, Black Warrior, Illinois, and Michigan basins discussed in this report were formed adjacent to the rising Appalachian Orogeny. These basins were part of a massive basin covered by a large sea that 
extended between the Appalachian Uplift and the Cratonic Shield of Canada. Sediments of Paleozoic Age ( $>300$ million years ago) originated from the erosion of these two highlands to form the clastic components, sandstones, and shales. Shallow marine deposition formed the carbonates, limestones, dolomites, and evaporites. The rise of the Cincinnati Arch, Finlay Arch, Kankakee Arch, Nashville Dome, and Wisconsin Dome in the middle Paleozoic separated the single basin into their present basins. Over millions of years, the unconsolidated sediments have become cemented. Most of the formations in the basins are composed of low-permeability, low-porosity consolidated rock. Oil and gas in the Appalachian, Black Warrior, nlinois and Michigan basins are found in Ordovician through younger age rock including Silurian, Devonian, Mississippian, and Pennsylvanian. Most of the oils within these basins are sweet paraffinic with high API gravity. Minor amounts of heavy oil have been discovered in four fields in the Michigan Basin (East Detroit Field, Henson Springs Field, McCracken Mountain Field, and Sand Springs Field) and two fields in the Illinois Basin (Carlinville North and Omaha).

The basins have an extensive infrastructure supporting local, aging, rapidly declining primary, and waterflood light oil production. The Appalachian, Black Warrior, Illinois and Michigan basins produce small volumes of heavy oil ( $10^{\circ}$ to $20^{\circ}$ API gravity or 100 to $10,000 \mathrm{cP}$ ) from consolidated reservoir rocks of Paleozoic Age. With cumulative heavy oil production of $450,000 \mathrm{bbl}$ of an estimated 14,000,000 bbl originally in place, the Appalachian, Black Warrior, Illinois, and Michigan basins are very minor heavy oil producing areas. Because of the mature state of exploration and production in these basins. However, discovery of small heavy oil deposits are possible. The discovery of new, large heavy oil resources is unlikely. Significant oil production by thermal recovery is unlikely because most of the reservoirs are carbonates. Horizontal wells and infield wells are not expected to be drilled to recover heavy oil resources in the Appalachian, Black Warrior, Illinois, and Michigan basins because of the small cumulative production.

The Appalachian, Black Warrior, Illinois, and Michigan basins have been major sweet, light oil producers with an extensive network of light oil collection and transportation lines going to small predominantly light, sweet oil refineries. The heavy oil that is refined in the Midwest and Eastern U.S. is imported and refined at select refineries. Imports of all grades of crude oil account for $37 \%$ into the Midwest and $>95 \%$ into the East Coast. The crude oil collection system will continue to degrade as light oil production declines and smaller refineries close due to lack of local, sweet, light oil and economies of scale. Select major refineries in the area will refine increasing volumes of imported higher sulfur, lower gravity crude oil from Canada, and Venezuela to meet the regions' liquid fuels needs Select East Coast refineries will process increasing volumes of light Mideast crude. The demand for crude oil will increase pipeline and tanker transport of imported crude to select large refineries. 
The potential environmental problems from implementation of limited thermal enhanced oil recovery (TEOR) processes are minimal because of the anticipated very low heavy oil production and the nature of the resource. Limited local development in these consolidated reservoirs may be attempted if the price of heavy oil were to increase significantly. A significant volume of low pour point paraffinic oil is known to exist in these basins. These reservoirs have not been included because of lack of viscosity and reservoir data, thus an outline of their geology is presented in the form of structure maps and stratigraphic columns along with references which can be used in future studies to determine the magnitude of the resource and constraints to oil production.

\section{OBJECTIVE OF THE STUDY AND STRUCTURE OF REPORT}

The objectives of this feasibility study and report are (1) to investigate from secondary data the heavy oil resources in the Appalachian, Black Warrior, Illinois and Michigan basins of the Midwest and Eastern United States; (2) to screen this resource for potential enhanced oil recovery applications; and (3) to evaluate various economic facets that may impact the development of this resource. If the study determines that expansion of production of heavy oil is economically possible with recent advances in technology, recommendations will be made to facilitate the production of this resource.

As one of a series of reports on the feasibility of heavy oil recovery in the U. S., this study analyzed the geologic settings of the Appalachian, Black Warrior, Illinois, and Michigan basins heavy oil fields and found very limited heavy oil resources. This review of secondary publicly available data attempts to list the constraints to heavy oil production, the transportation network, refining capabilities, environmental restrictions, and economic considerations that impact heavy oil development. NIPER's analysis of the secondary field data is included in Table A-1.

Heavy oil is defined as having gas-free viscosity of $>100$ and $<10,000$ MPas (centipoise, cP) inclusive at original reservoir temperature or a density of $943 \mathrm{~kg} / \mathrm{m}^{3}$ (20 API gravity) to 1,000 $\mathrm{kg} / \mathrm{m}^{3}\left(10^{\circ} \mathrm{API}\right.$ gravity) inclusive at $15.6^{\circ} \mathrm{C}\left(60^{\circ} \mathrm{F}\right)$ (Group, 1981). These Eastern U.S. basins contain a large volume of paraffinic oil in old fields which are pressure depleted and whose light ends have been vented. Very little data was found on reservoirs with paraffinic low pour point oil because of data bases rarely include oil viscosity. Therefore, the number of reservoirs that could qualify as heavy oil may be significantly larger than reported herein. Several of the paraffinic low pour point reservoirs, both clastic and carbonate, would be amenable to thermal oil recovery but have not been included because of lack of published public data. 


\section{BACKGROUND AND DISCUSSION}

The major U.S. petroleum basins are shown in Fig. 1. The Appalachian, Black Warrior, Illinois, and Michigan basins are the major sedimentary basins in the Eastern United States, exclusive of the Gulf Coast. The geographic extent of these basins and their relationship to the structural features and igneous and metamorphic rocks of the Eastern Unites States are shown in Fig. 2. Deposition in these sedimentary basins is primarily shallow marine and fluvial-deltaic clastics eroded from the rising mountain chains of the Appalachian Highlands. The uplift of the Cincinnati Arch in the late Ordovician was a major factor in separating these sedimentary basins into individual basins.

\section{Appalachian Basin}

The Appalachian Basin is the largest basin in the United States (Figs. 1 and 2) and extends south from central New York to include the western two-thirds of Pennsylvania, eastern Ohio, most of West Virginia, eastern Kentucky, part of western Virginia, and north-central Tennessee (Landes, 1970; Bayer, 1982). The Appalachian Basin is bound on the east and south by the Appalachian Highlands. It is bound on the north by the Adirondack Uplift and on the west by the Cincinnati Arch (Fig. 2) (Landes, 1970; Ingham, 1971). Oil and gas production has been from the Paleozoic Age rocks forming the northeast to southwest trending basin (Landes, 1970; Patchen, et al., 1989). Extensive fault zones along the Blue Ridge, Allegheny Front, and Brevard Fault uplifted the Appalachian Mountain chain (Figs. 3 and 4) (Bayer, 1982; DeWitt and Milici, 1989). Paleozoic sediments formed the broad, deep Appalachian Basin west of the mountains. The thickners of Paleozoic strata ranges from $1,800 \mathrm{ft}$ to $3,000 \mathrm{ft}$ on the western flank of the basin against the Cincinnati Arch to 40,000 ft thick in central Pennsylvania (DeWitt and Milici, 1989).

Stratigraphic columns for the Paleozoic rocks of the Appalachian Basin show the relationship of widespread limestone and sandstone intervals in the northern Appalachian Basin (Figs. 5, 6, and 7) and in the central and southern part of the basin (Figs. 8, 9, 10, and 11). Some of these units can be correlated across most of the Appalachian Basin. The Middle Ordovician Black River and Trenton limestones are the most continuous marker intervals in the Appalachian Basin (Figs. 6, 7, and 10, and 11) (Ryder, 1988; Landes, 1970). The Black River and Trenton Formations of Ohio, Pennsylvania, West Virginia, Virginia, and New York correlate with the High Bridge and Lexington limestones of Kentucky and the Stones River and Nashville Groups of Tennessee (Figs. 8 and 9) (Ryder, 1988; Landes, 1970).

Deeper Paleozoic rocks of Cambrian and Ordovician Age produce small quantities of hydrocarbons in the Appalachian Basin. The Trenton and Black River Ordovician limestones and their equivalents are the oldest producing units in the Appalachian Basin (Figs. 5 through 11). Oil 


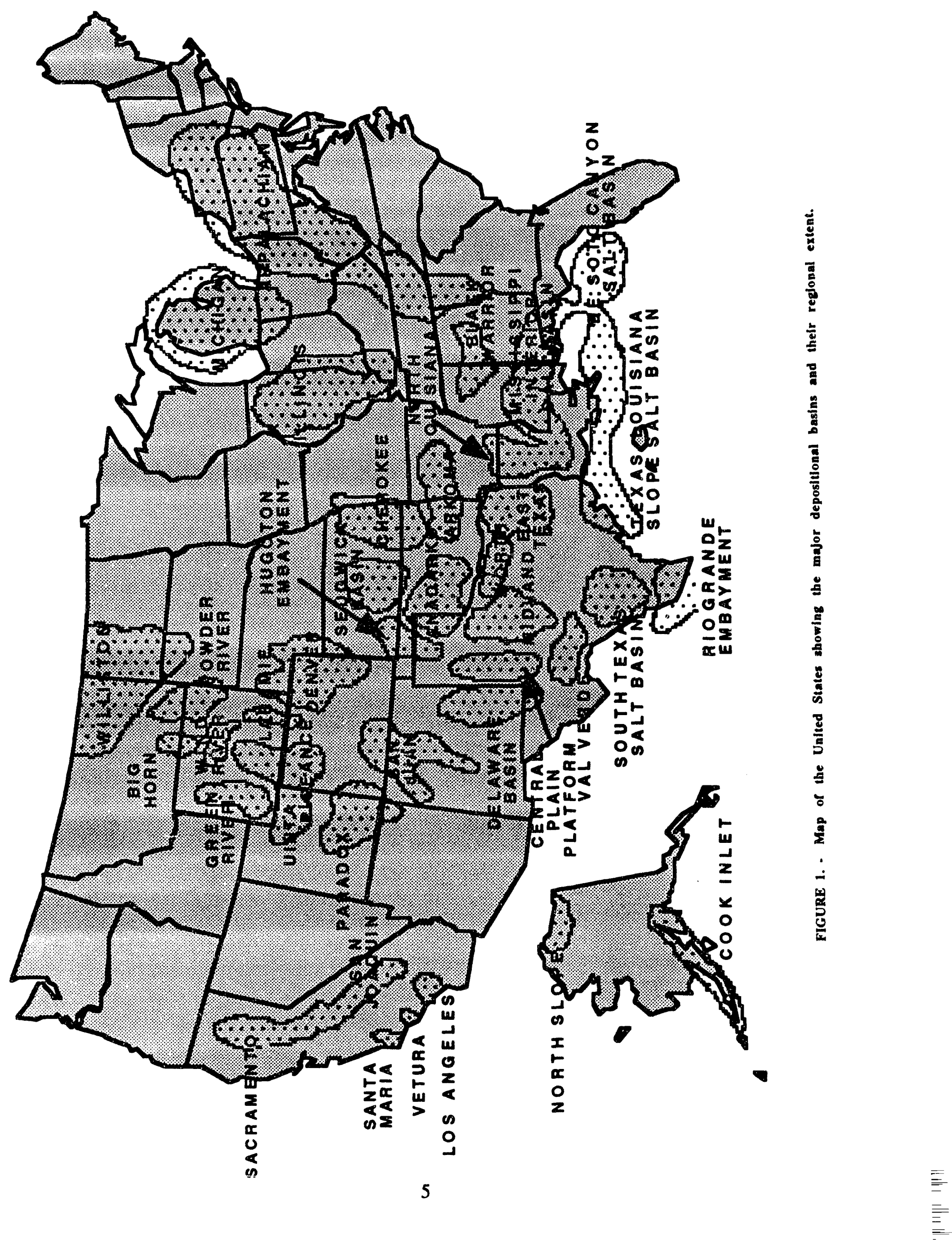




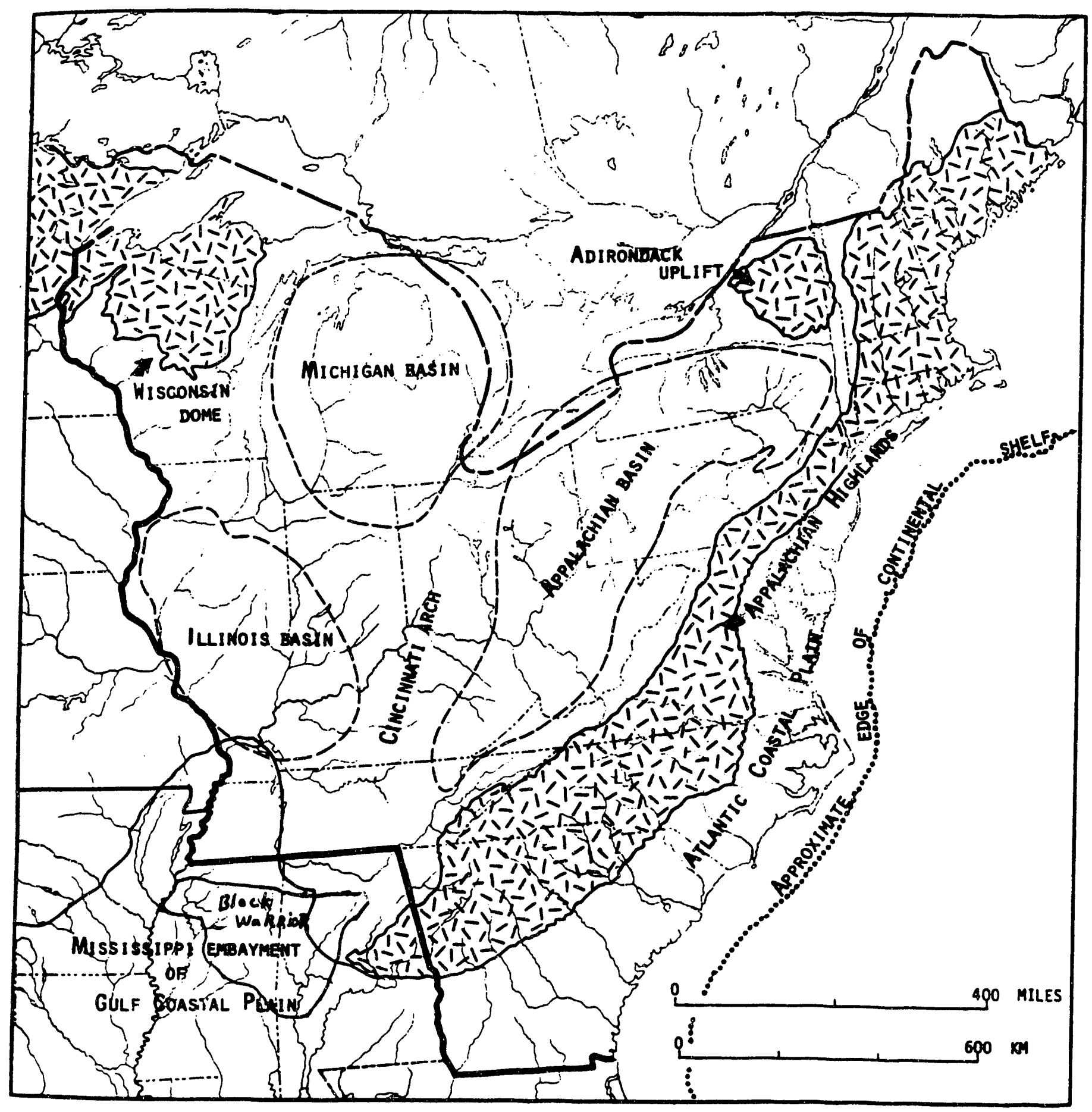

FIGURE 2. - The sedimentary basins of the Eastern United States are outlined by dashed lines. Palterned areas outline crystalline rock, Precambrian basement and Paleozolc Igmeous and metamorphic rocks. After Landes, 1970. 


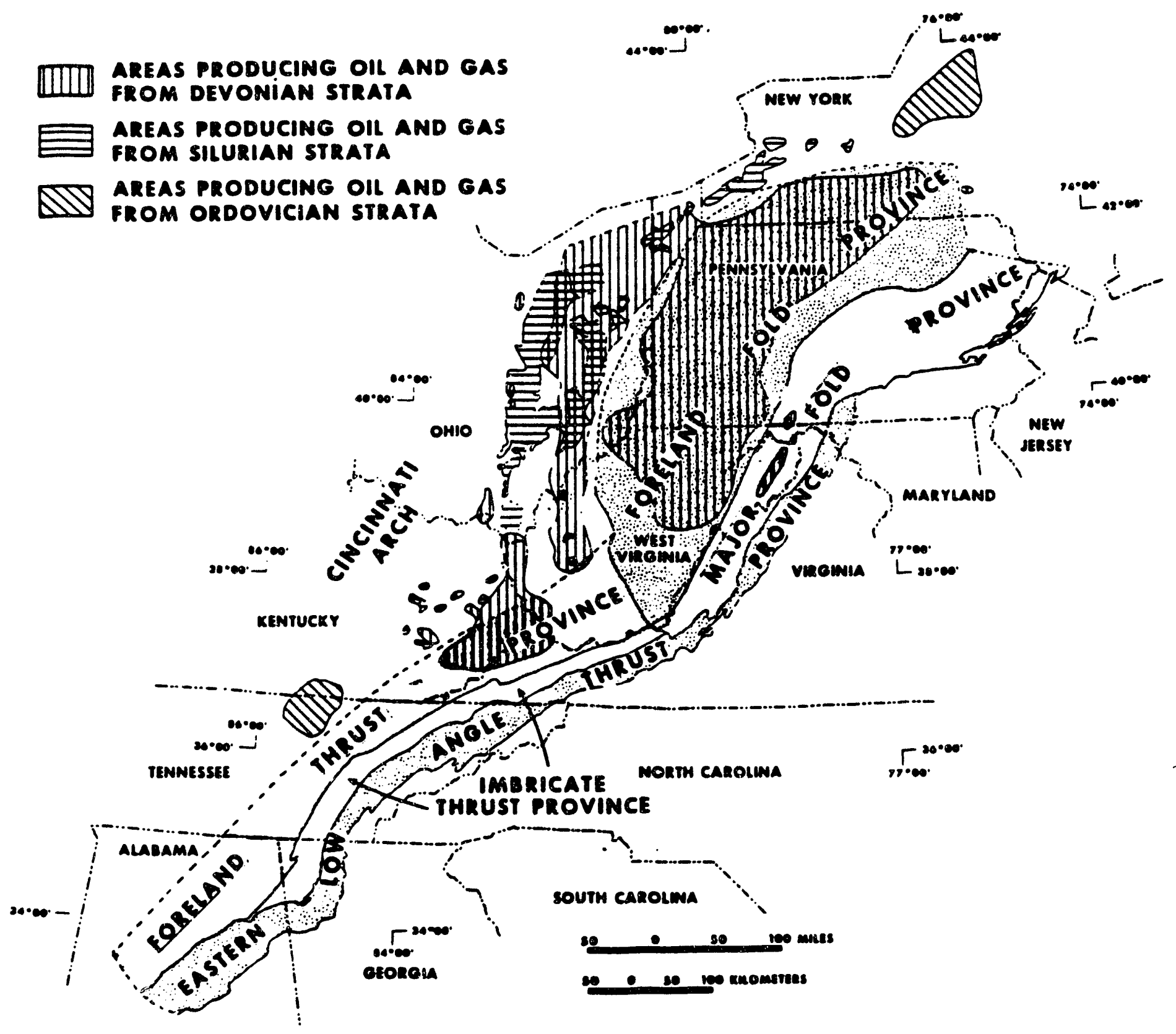

FIGURE 3. - The Appalachian Basin showing the relationship of hydrocarbon producing areas to redional structure. After DeWitt and Milici, 1989. 


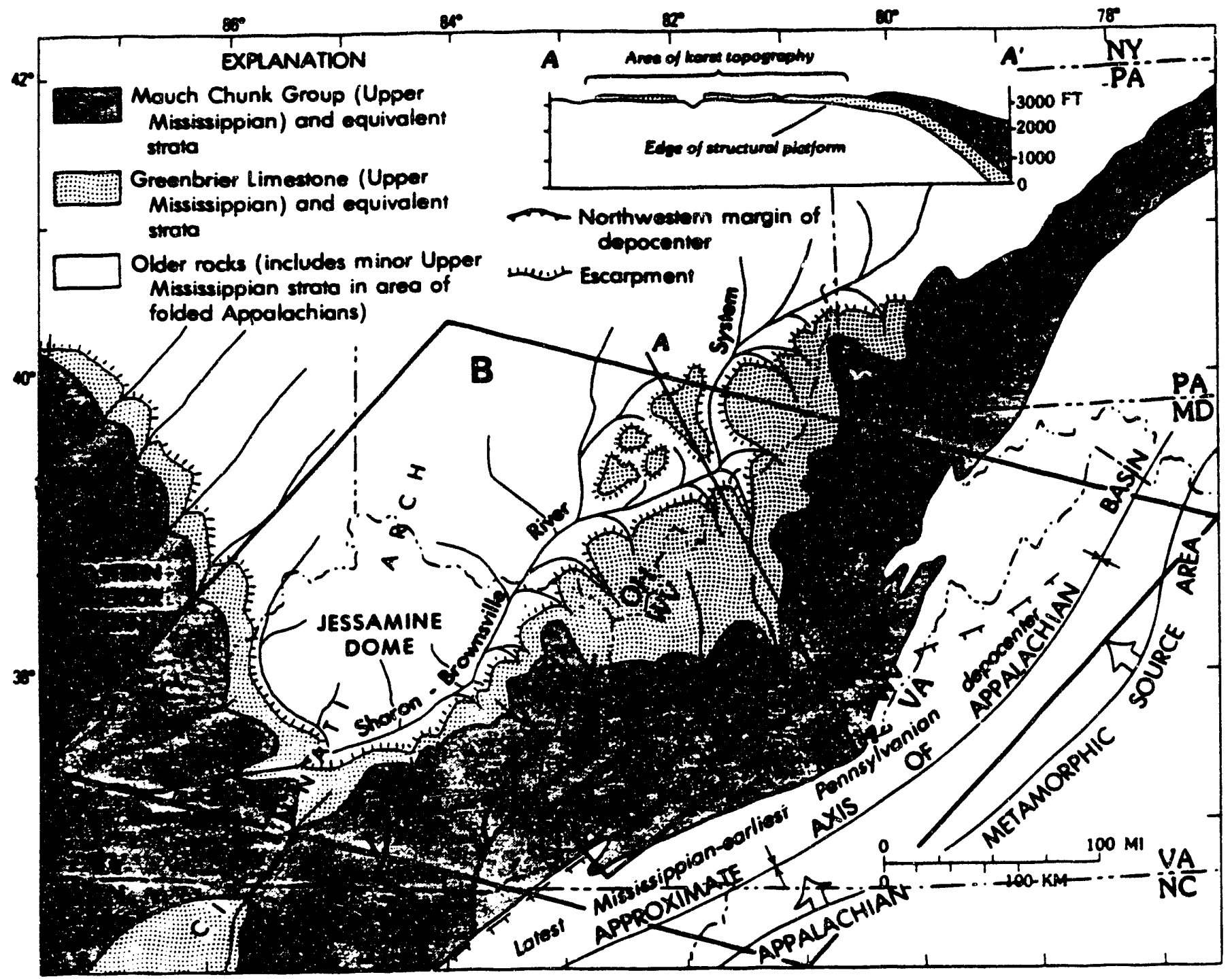

FIGURE 4. - The distribution of Upper Paleozolc sedimentary rocks and structural relatlonshlps for the central A zpalachlan Basla. After Rice and Schwietering, 1988. 


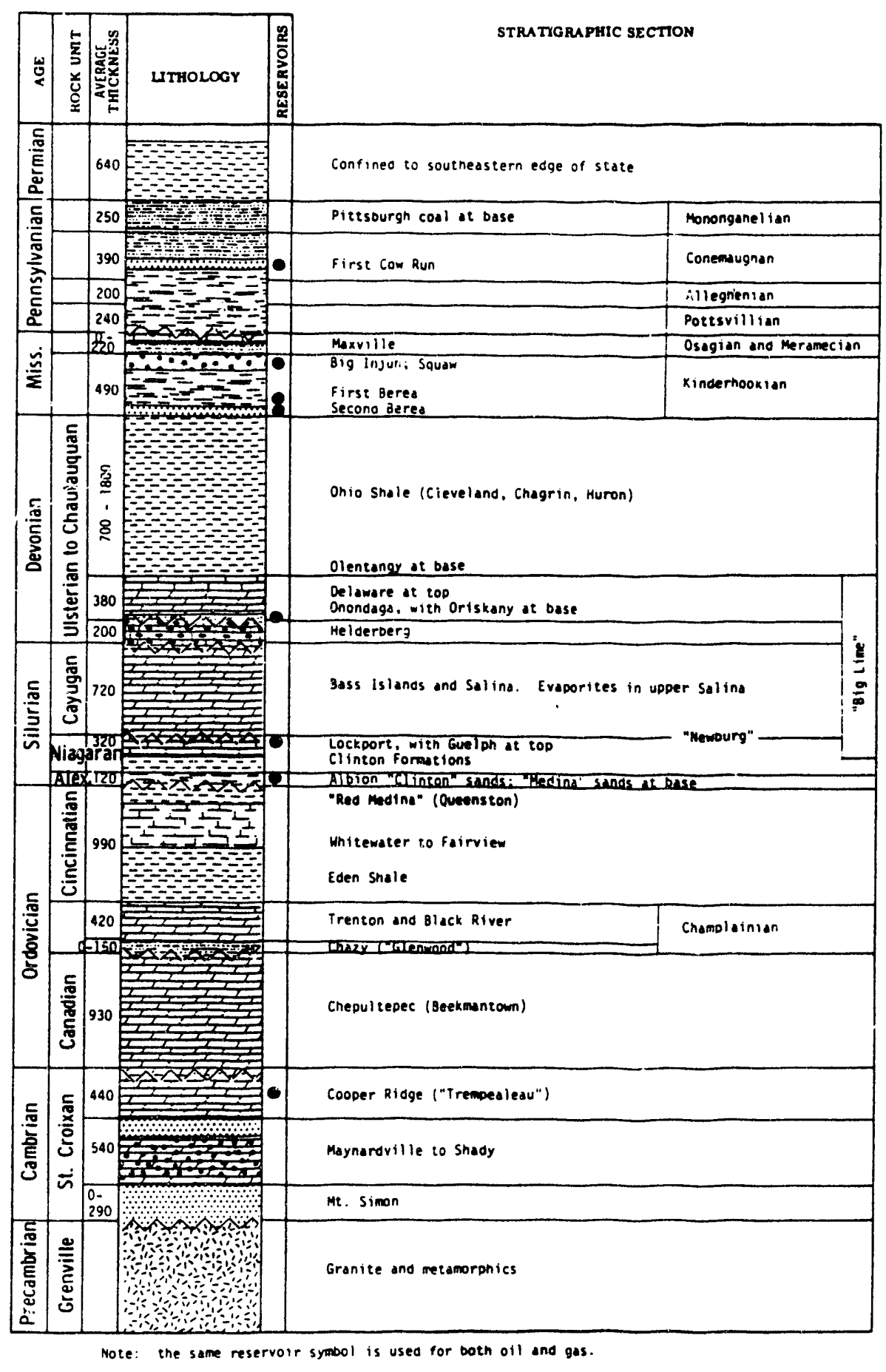

FIGURE 5. - Stratlgraphic columns for Ohlo. After Landes, 1970. 


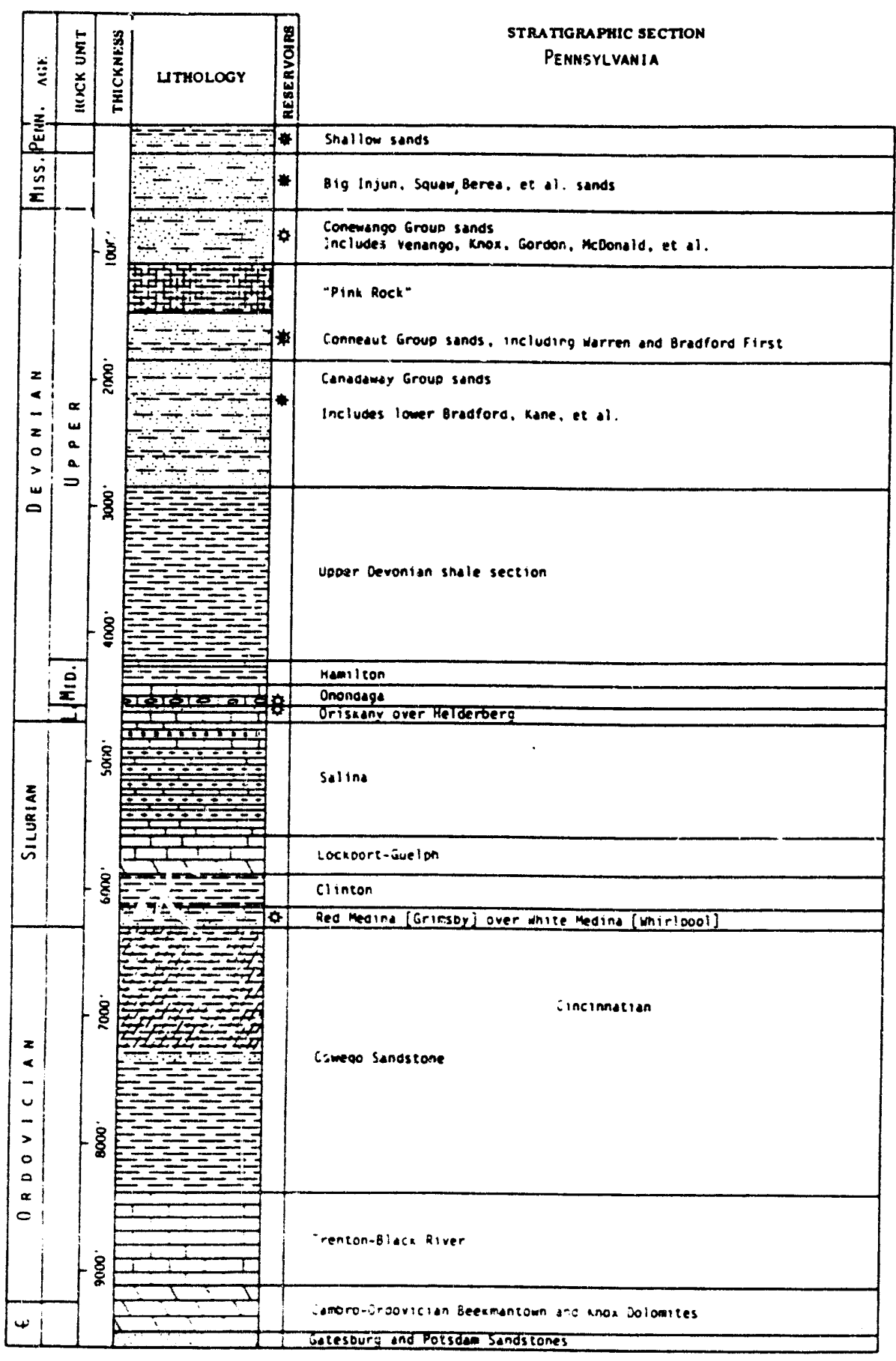

FIGURE 6. - Stratieraphle columas for Pennsylvania. After Landes, 1970. 


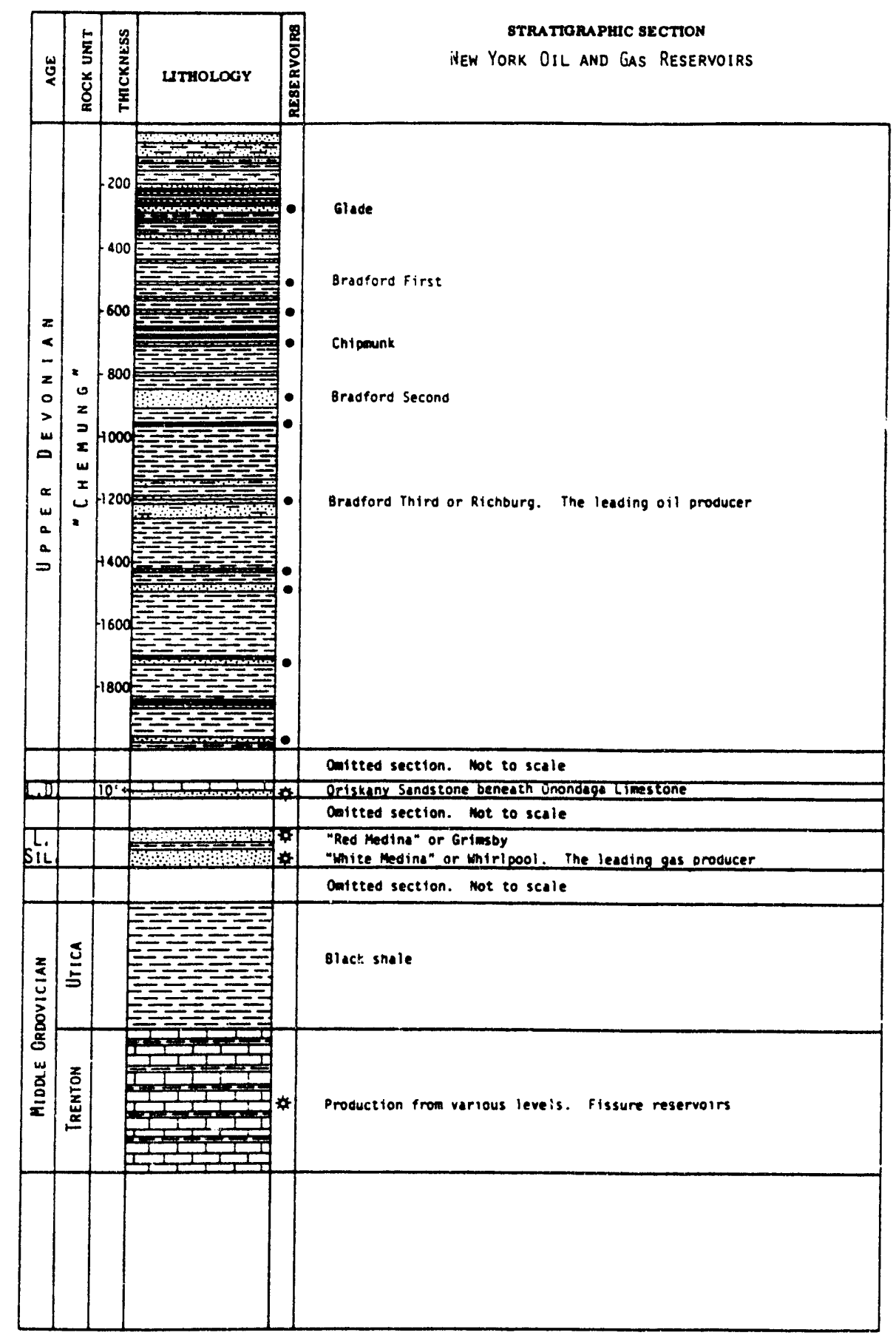

FIGURE 7. - Stratioraphic columns for New York. After Landes, 1970. 


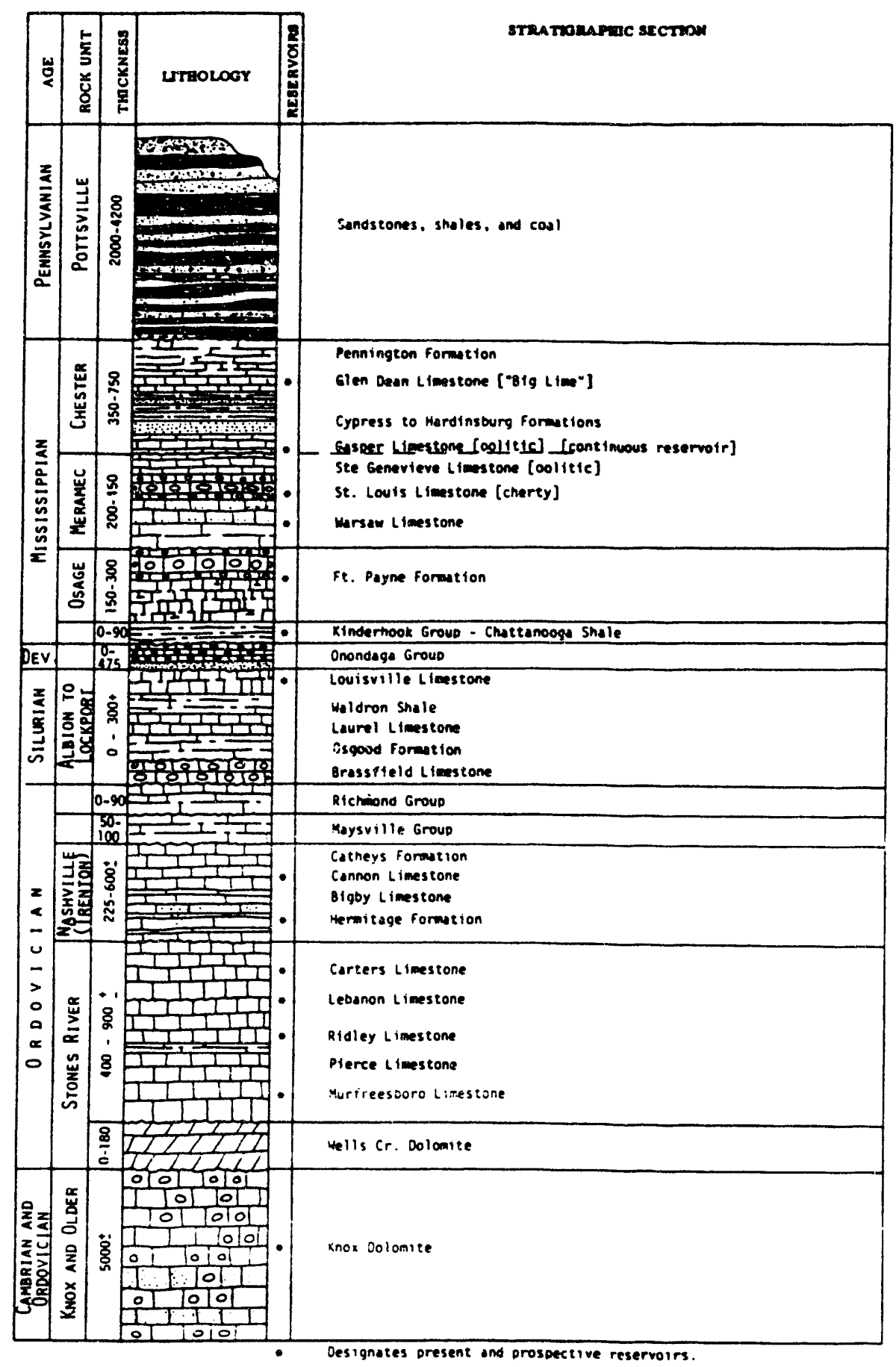

FIGURE 8. - Stratigraphle columns for Tennessee. After Landes, 1970. 


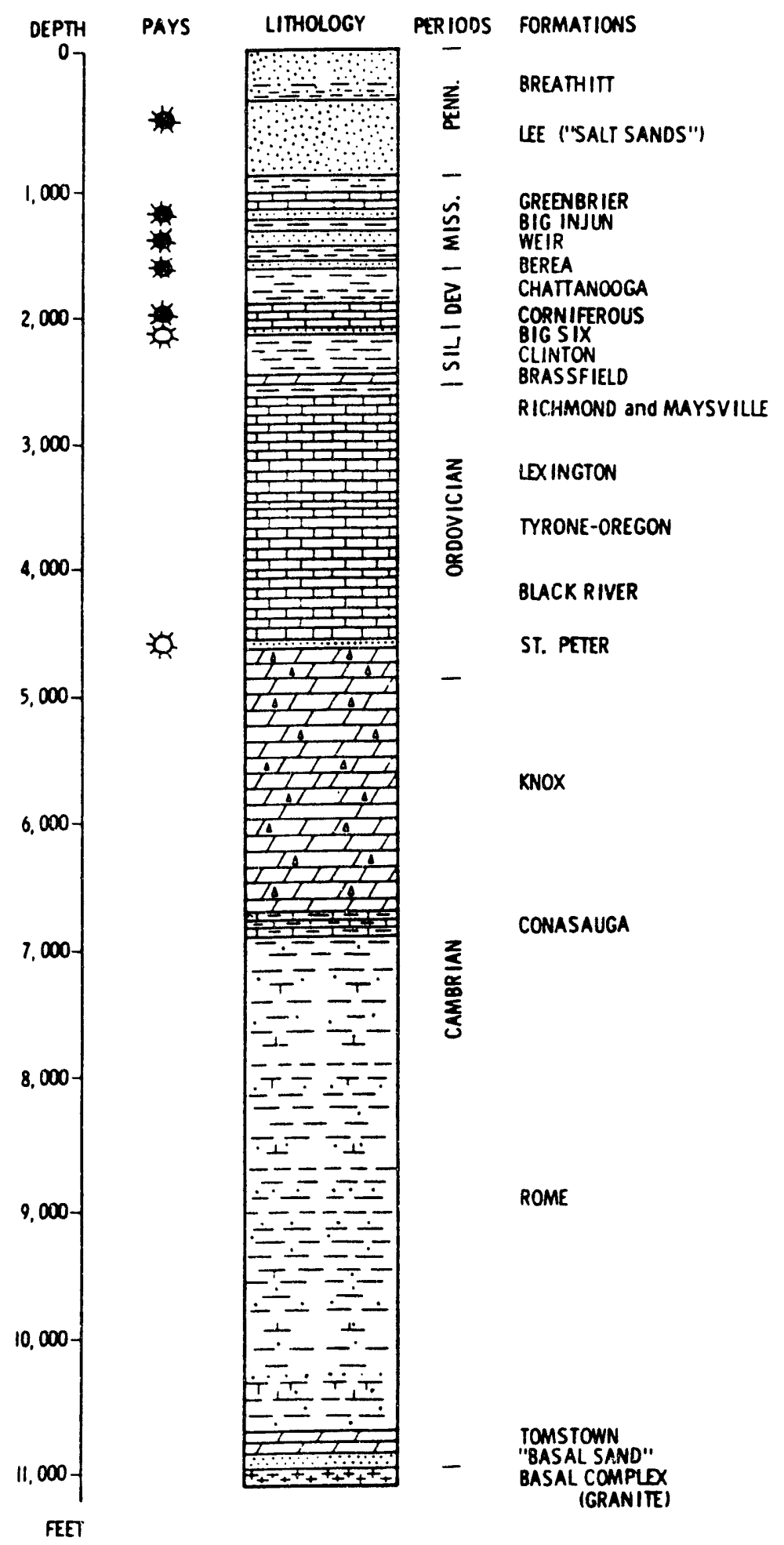

FIGURE 9. -Stratigraphlc columns for Keatucky. After Landes, 1970. 


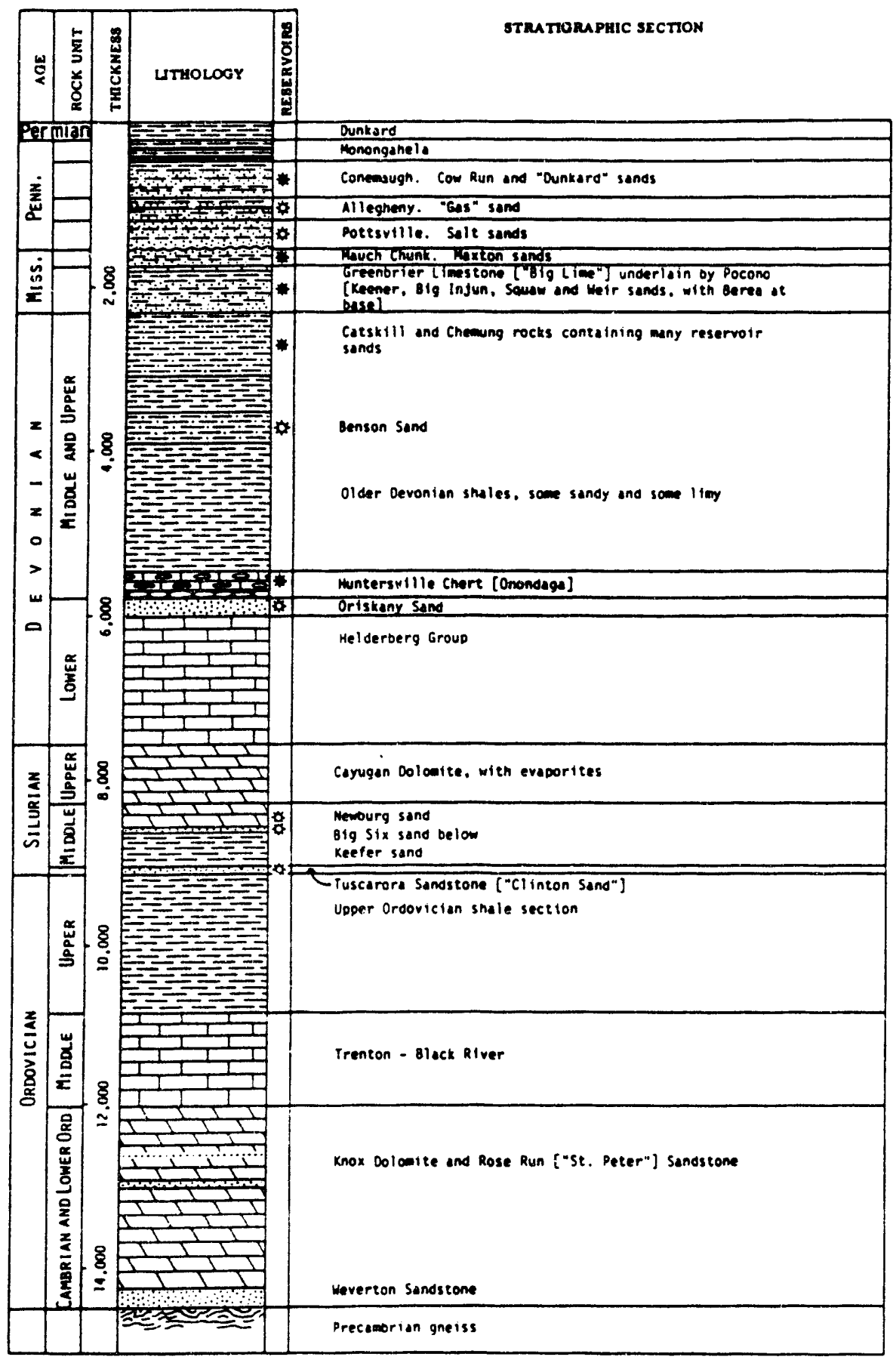

FIGURE 10. - Stratigraphic columas tor West Virginia. After Landes, 1970. 


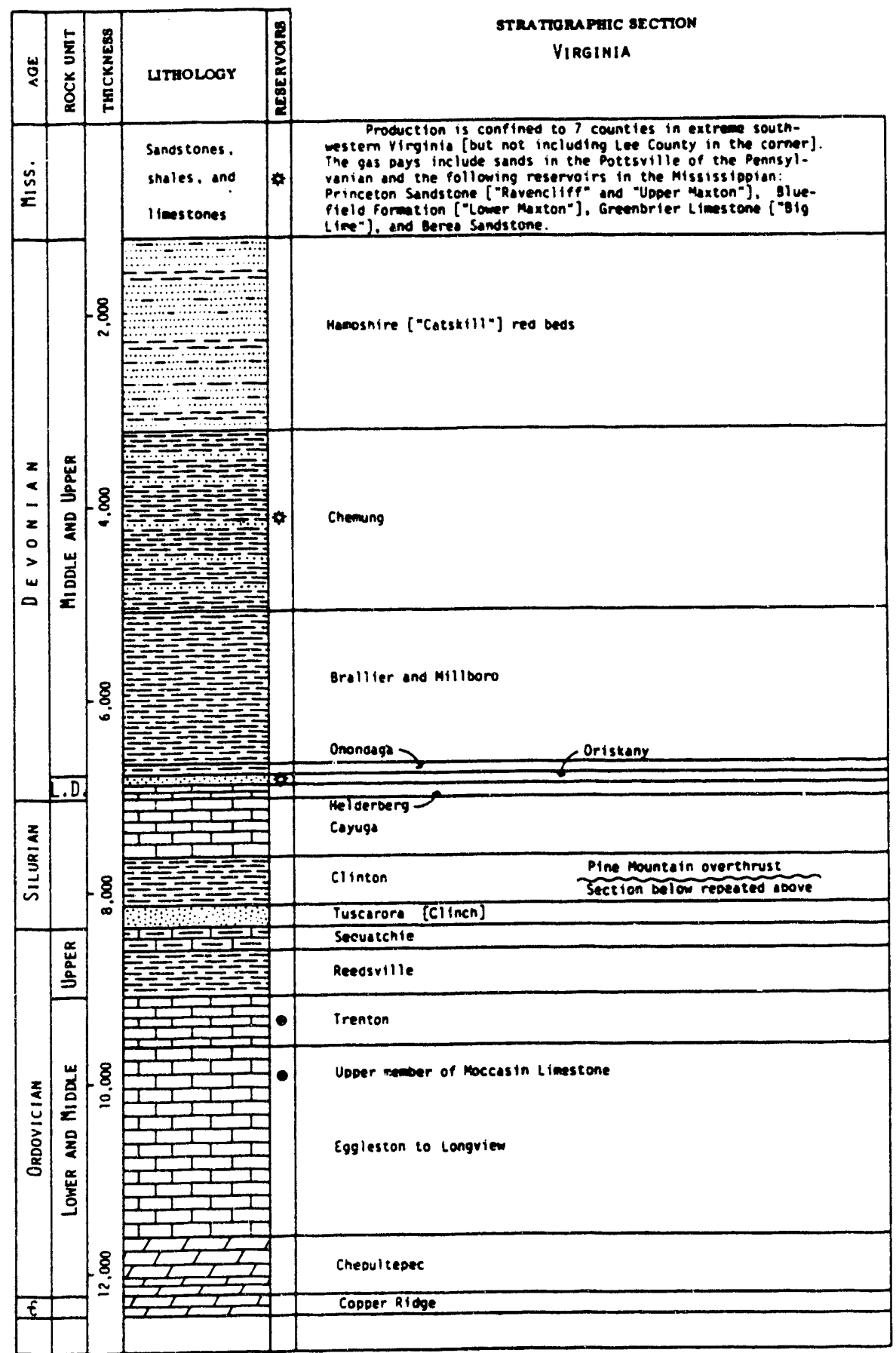

FIGURE 11. - Stratigraphic columas for Virgiala. After Landes, 1970. 
is also produced from the Upper Ordovician Moccasin limestone in Virginia (Landes, 1970). The Middle and Upper Ordovician strata have a combined thickness of over 5,500 ft in Pennsylvania, West Virginia, and Virginia (Ryder, 1988).

In the more northem portion of the Appalachian Basin, oil production is primarily from Devonian Age strata (Figs. 5, 6, 7, and 10) in New York, Pennsyivania, and less so in Ohio and West Virginia. New York is a minor producer of oil, whereas Pennsylvania still ranks high in production of high-quality, light, paraffinic oil from Upper Devonian, Mississippian, and Pennsylvania rocks (Patchen, et al., 1989; Landes, 1970).

More productive intervals are found in the southern Appalarhian Basin from various age Paleozoic strata. Wells in eastern Ohio produce from Ordovician limestones, Silurian shales and dolomites, shallow Mississippian sands (Brea Formation) and Pennsylvanian sands (Cow Run Formation) (Patchen, et al., 1989). Production in West Virginia has been from Upper Devonian sands, Mississippian sands and limestones, and Pennsylvanian sands. The main oil producing formations in West Virginia are the Greenbrier limestones (Fig. 12) and the Cow Run and Dunkard sandstones (Patchen, et al., 1989; Landes, 1970). In Virginia, oil is produced from Ordovician Trenton and Moccasin limestones, and gas from Devonian and Mississippian strata (Patchen, et al., 1989; Landes, 1970). Eastern Kentucky produces oil from Silurian Niagaran shales, Silurian and Devonian dolomites, Mississippian (Greenbrier) limestones, and Pennsylvanian sandstones (Lee and Breathit Formations, Fig. 12) (DeWitt and Milici, 1989; Landes, 1970).

Figure 3 shows the major oil and gas producing strata of the Appalachian Basin as they relate to the structure of the thrust belt forming the Appalachian Mountain chain (DeWitt and Milici, 1989). Structural developments in the central part of the Appalachian Basin occurred during Upper Mississippian and Pennsylvanian periods, as shown in Fig. 12 (Rice and Schwietering, 1988). During this period, the Cincinnati Arch was emergent, and Greenbrier limestones gave way to sandstones and conglomerates (Fig. 10) (Rice and Schwietering, 1988; DeWitt and Milici, 1989).

Tennessee produces only minor amounts of oil compared to the other Appalachian Basin states (Landes, 1970). The producing counties of Tennessee are in the north-central part of the state near the Kentucky border and are in the portion of the southern end of the Appalachian Basin between the Cincinnati Arch and the Nashville Dome of the Appalachian Highlands (Fig. 2) (Landes, 1970).

The abundant oil produced in the Appalachian basin falls in the category of light oil. The U.S. Geological Survey does not list any heavy oil fields in New York, Pennsylvania, Ohio, West Virginia, Virginia, Kentucky, or Tennessee (Crysdale and Schenk, 1990). Kentucky has deposits of tar with specific gravities below $10^{\circ}$ API (McGrain and Ponsetto, 1981). These deposits are not associated with any measurable amounts of heavy oil in the $10^{\circ}$ to $20^{\circ}$ API range. However, the Appalachian basin contains significant low pour point paraffinic oil whose resource volume has 


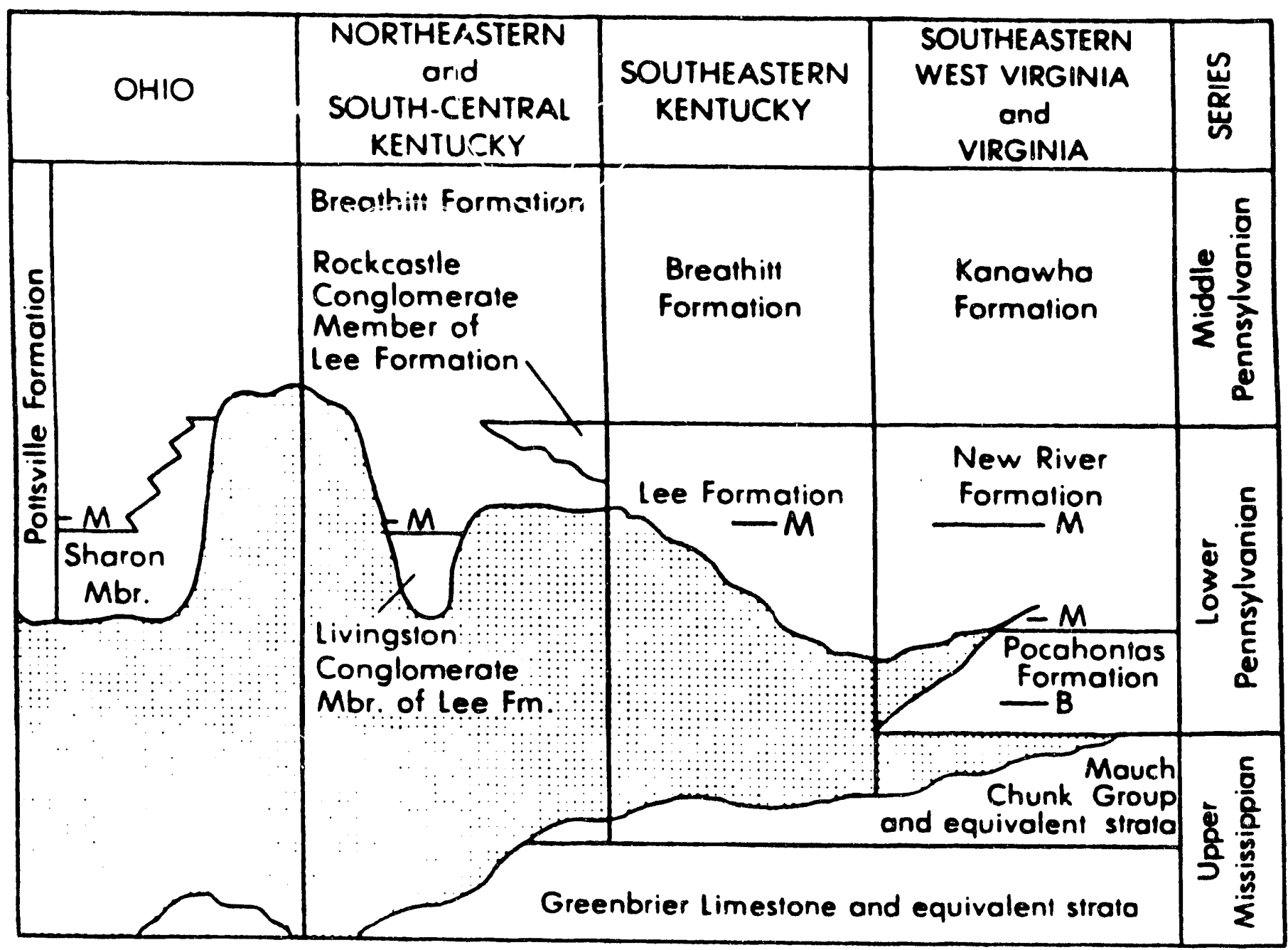

FIGURE 12. - A correlatlon chart of Upper Paleozole stratlgraphy in the Central Appalachian Basin. After Rice and Schwletering, 1988; Arkle, 1974; Englund, 1974; Rice, 1984; and Wanless, 1975. 
not been determined because oil viscosity data is not continually compiled. Records for states in this area are not as extensive and production is often listed only by county, not field or reservoir.

\section{Black Warrior Basin}

The Black Warrior Basin's oil and gas fields of Alabama and Mississippi produce from rocks of Ordovician, Devonian, Mississippian, and Pennsylvanian Ages (Figs. 13 through 15). The Carter Sandstone of the Parkwood Formation of Mississippian Age is the most prolific producer. The Lewis Limestone in the Floyd Shale of lower Mississippian Age and the Millerella sandstone and limestone and Gilmer sandstone of the Upper Parkwood Formation are also good producing intervals (Epsman, 1987).

The stratigraphic column (Fig. 15) for the Black Warrior basin pinpoints the intervals of major production (Epsman, 198\%). The Pennsylvanian sandstones are widely distributed, but much less productive. Potential for hydrocarbon reservoirs exists in the deeper part of the basin where Pennsylvanian sandstones reach thicknesses of over $5,000 \mathrm{ft}$. (Epsman, 1987). Carbonate reservoirs within the Black Warrior basin produce some hydrocarbons from Bangor and Tuscumbia limestones of the Upper Mississippian. Devonian rocks have potential as hydrocarbon reservoirs, but they have not been tested sufficiently. Most wells in the Black Warrior Basin do not go deep enough to penetrate the Devonian sediments (Epsman, 1987). A single Middle Ordovician Age reservoir produces in the Fairview Field from the Stones River Group of limestones and dolomites.

The Black Warrior basin is a homocline extending beneath the Appalachian-Ouachita structure (Beardsen, 1985; Epsman, 1987). Figure 16 shows the complex faulting in the Black Warrior Basin in Alabama (Epsman, 1987). The trapping mechanism in this structural basin (Fig. 16) is a series of northwest-southeast oriented fault systems (Beardsen, 1985; Epsman, 1987). A gently plunging anticline gives a secondary structural feature to aid in trapping (Epsman, 1987). These structural traps, combined with stratigraphic features of updip pinchout of sand porosity, account for $46.9 \%$ of the reservoirs in the Black Warrior Basin (Epsman, 1987). Stratigraphic traps of depositional and diagenetic porosity pinchouts account for $40.6 \%$ of the traps (Epsman, 1987). Only 12.5\% of the traps are strictly structural in nature (Epsman, 1987).

In Mississippi, the Black Warrior basin occupies the northern part of the Mississippi Embayment (Fig. 14A) (Landes, 1970). Paleozoic hydrocarbon producing formations lie within 6,000 ft of the surface (Landes, 1970). The surface sediments are Cretaceous in age. The Central Mississippian Salt Basin is far more productive than the portion of the Black Warrior Basin in Mississippi (Landes, 1970). Production in the Black Warrior Basin is predominantly from Mississippian Age sandstones equivalent to those in Alabama (Landes, 1970; Epsman, 1987). 


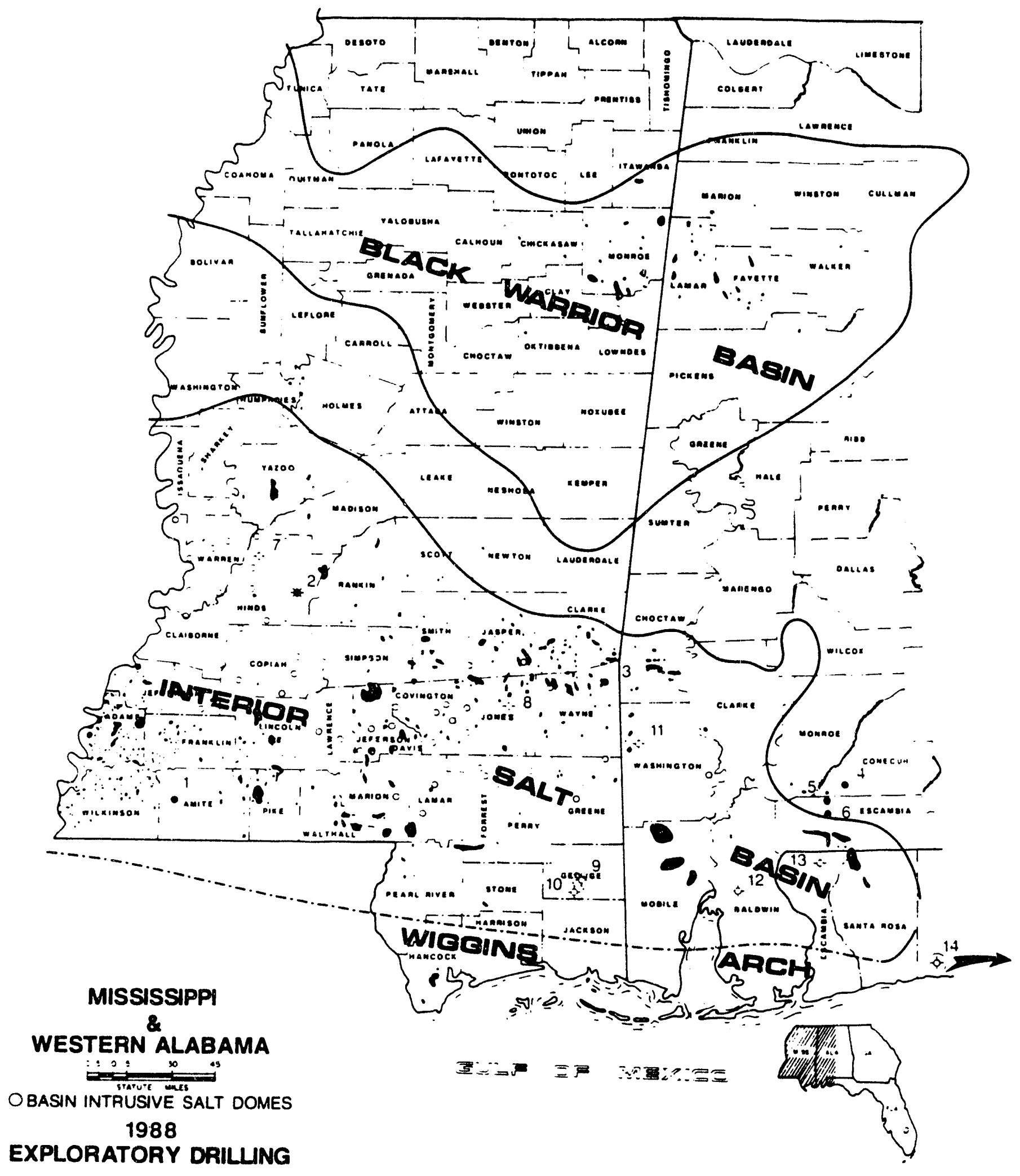

FIGURE 13. - Black Warrior Basin of Alabama and Misstsappl showing oll and gas nelds as of 1988. After Halvatzls, 1989. 


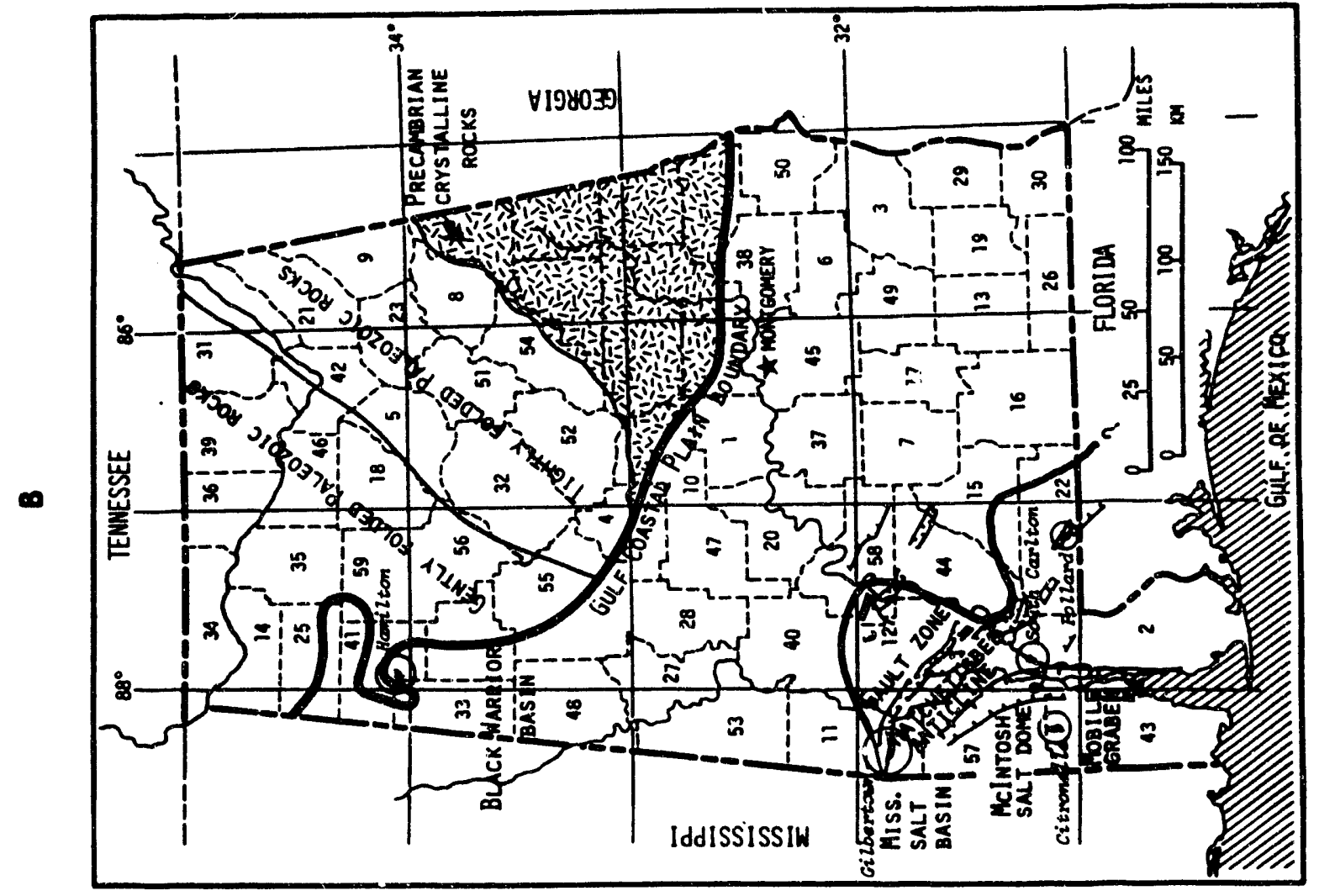

2

$\frac{\bar{a}}{\frac{3}{3}}$

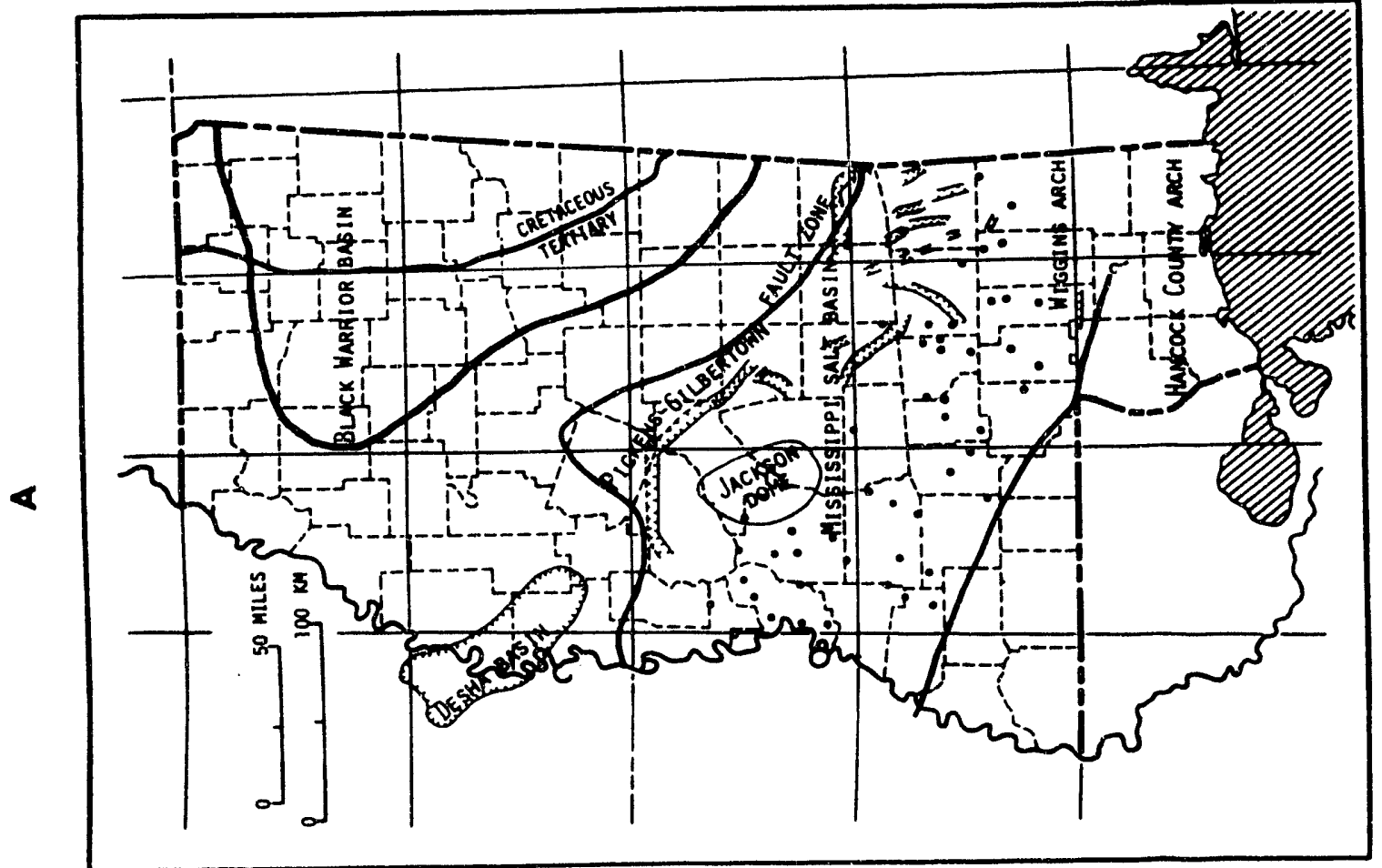

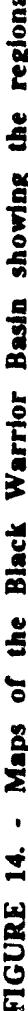




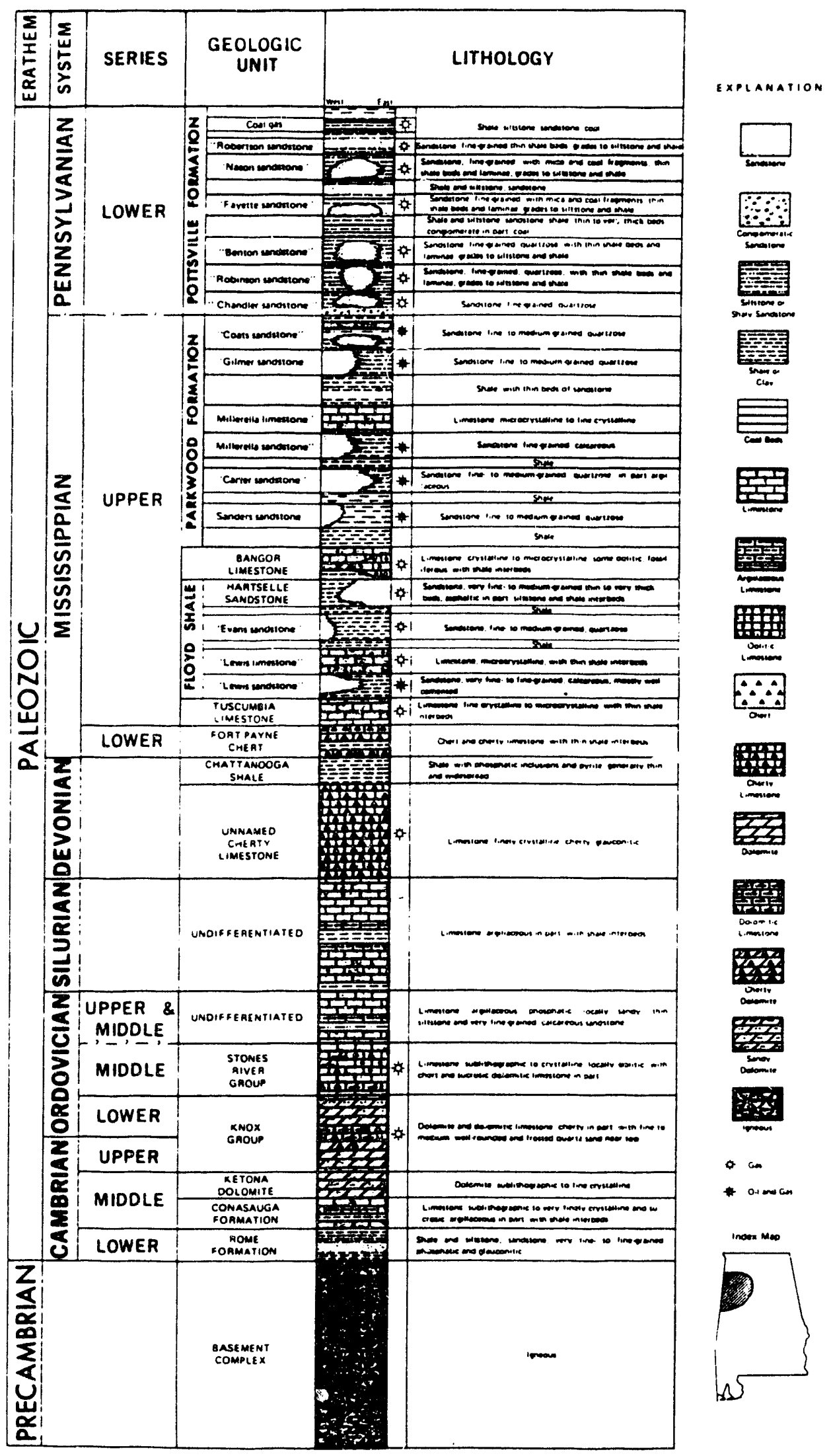

FigURE 15. - Stratigraphic column of the Black Warrior Bastn showing oll and gas producing areas. After Epsman, 1987. 


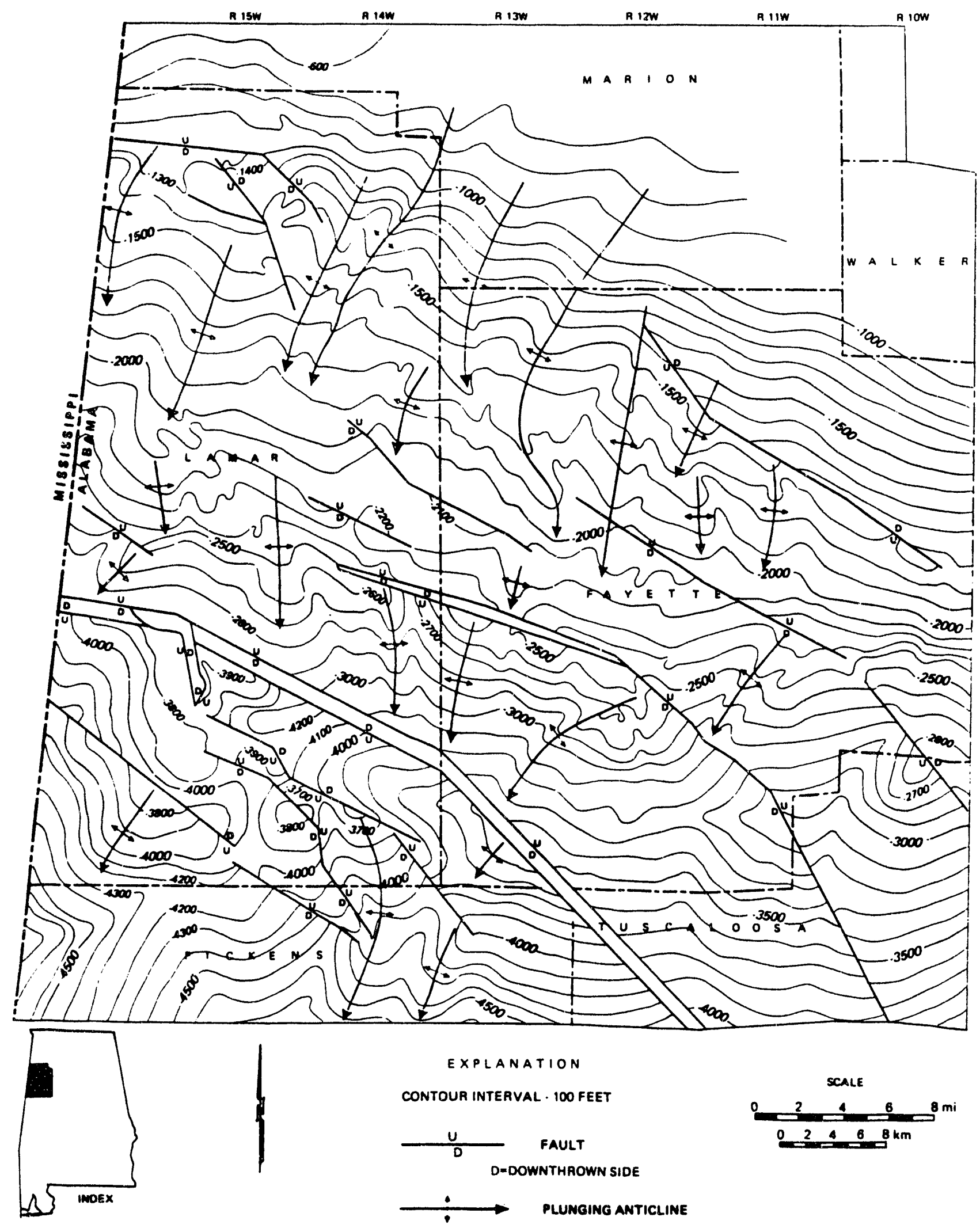

FIGURE 16. - A structure map of the Alabama portion of the Black Warrior Basin showing the complleated fault syatem which traps ofl and gas. After Epsman, 1987. 
Drilling for oil and gas in the Black Warrior Basin began in 1909 (Masingill, 1989). Gas wells predominated in the early years. In 1970, new drilling encountered the Carter Sand of Mississippian Age (Masingill, 1989). Oil produced from the Carter Sand led to further exploration in the 1970 s and 1980s. Production from depths of 1,300 to $2,500 \mathrm{ft}$ was mainly from the Upper Mississippian units of the Parkwood Formation (Masingill, 1989). Exploration in the 1980s has centered around coal degasification projects which have been highly productive (Masingill, 1989).

In the 1980s, extensive tests were drilled in the Black Warrior Basin (Halvatzis, 1985, 1989). The Paleozoic sediments of the Black Warrior Basin accounted for $34 \%$ of all exploraiory tests in the southeastern states in 1988 (Halvatzis, 1989). Limestones intervals at 6,000 ft or less were the principal targets (Halvatzis, 1989). Figure 13 shows the extent of fields in the Black Warrior Basin as of 1988 (Halvatzis, 1989). Specific gravities for fields in the Black Warrior Basin, as reported by Alabama Geological Survey, range from $29^{\circ}$ to $44^{\circ}$ API (Epsman, 1987).

Oil from the Black Warrior Basin is primarily light oil. The U.S.G.S. list of major heavy oil fields (Crysdale and Schenk, 1990) does not list any fields in the Black Warrior Basin as having crude oils with gravities of $20^{\circ} \mathrm{API}$ or below. Heavy oil in the range of $12^{\circ}$ to $20^{\circ} \mathrm{API}$ is produced from the Mid-Gulf Coast Basin in Mississippi and Alabama (Crysdale and Schenk, 1990). Heavy oil production is from intervals in the Cretaceous and Tertiary in Mississippi and Alabama (Crysdale and Schenk, 1990; Landes, 1970). Lighter oils are produced in the Black Warrior Basin, predominantly from Paleozoic sediments (Masingill, 1989; Epsman, 1987).

In the late 1980s, five minor heavy oil deposits were discovered in the Black Warrior Basin (Mississippi, 1989; Masingill, 1988). Amory Field is a gas production area and the heavy oil was found in association with gas. Paraffinic Alabama fields-East Detroit and Henson Springs in Lamar County, and Sand Springs in Fayette County-have tested heavy oil from the Carter sandstone (Masingill, 1988). McCracken Mountain Field in Fayette County, Alabama, has tested heavy oil from the Millerella sandstone (Masingill, 1988). Future exploration in these areas may lead to new discoveries of heavy oil in the Black Warrior Basin, although major deposits are unlikely.

\section{Illinois Basin}

The Illinois Basin is a regional downwarp covering most of Illinois, parts of western Indiana, and northwestern nentucky (Figs. 2 and 17). It is one of the largest intercratonic basins in the U.S. (Leighton and Kolata, 1991). A cross section of the Paleozoic sediments forming the Illinois Basin is shown in Fig. 18. The Paleozoic units (Fig. 19) range from 2,000 ft deep on the margins of the basins to over 13,000 $\mathrm{ft}$ deep in the center of the basin (Landes, 1970). The deepest part of the basin is at the junction of the Wabash and Ohio Rivers (Landes, 1970). 


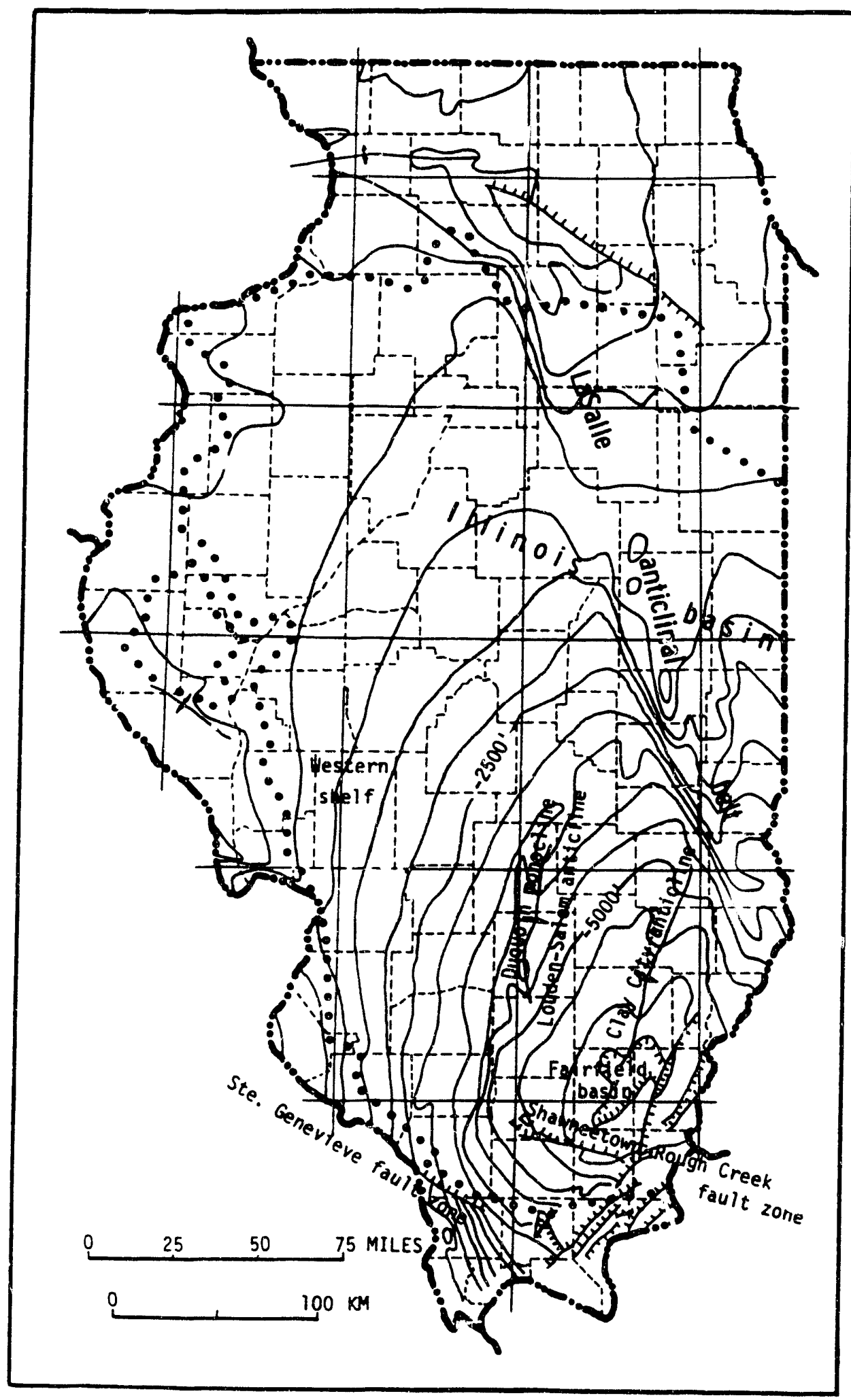

FIGURE 17. - The maln part of the Ilinols Basin, showing the fault zones and oll and gas exploration in 1984. After Gilbert et al., 1985. 


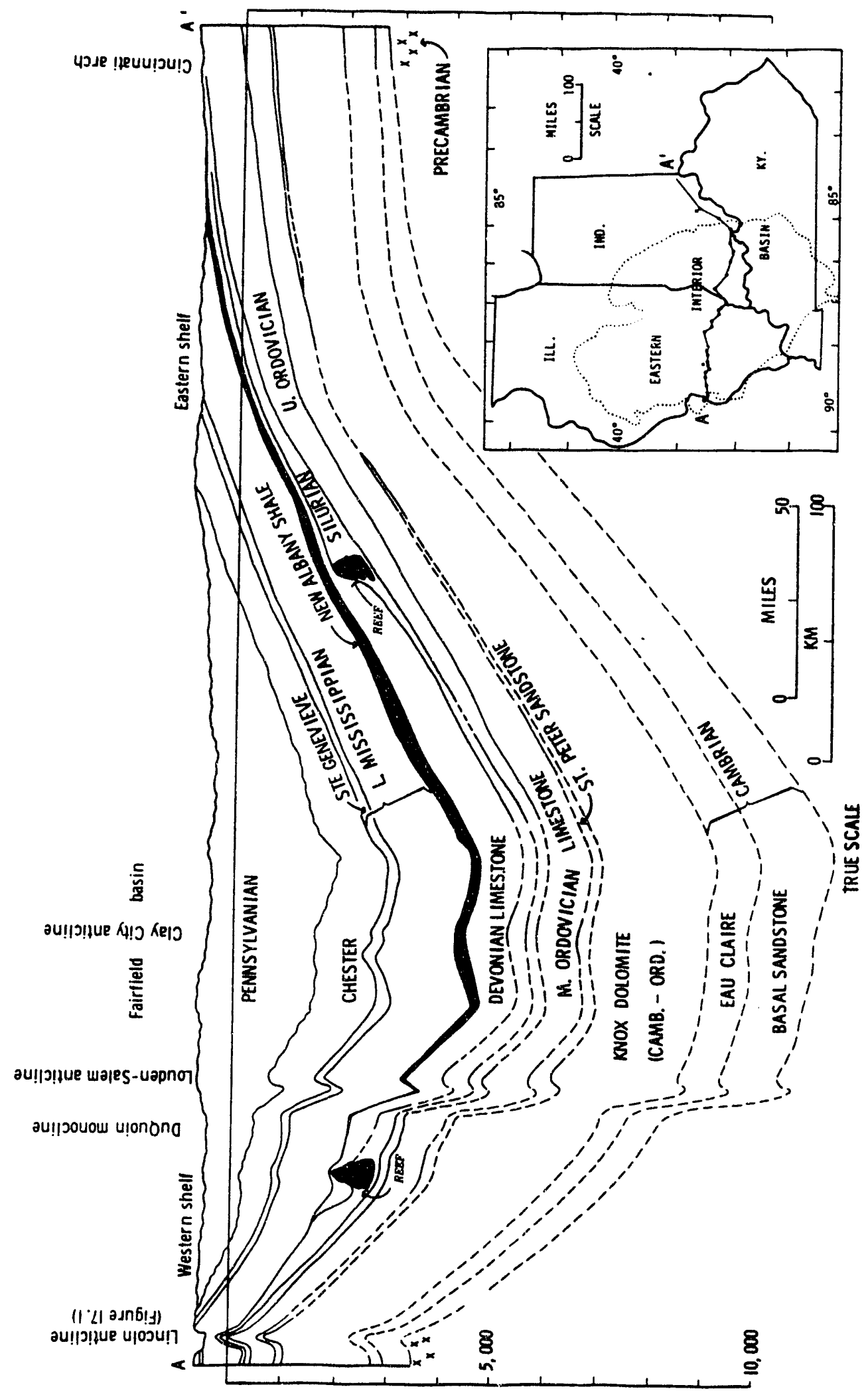

홍 


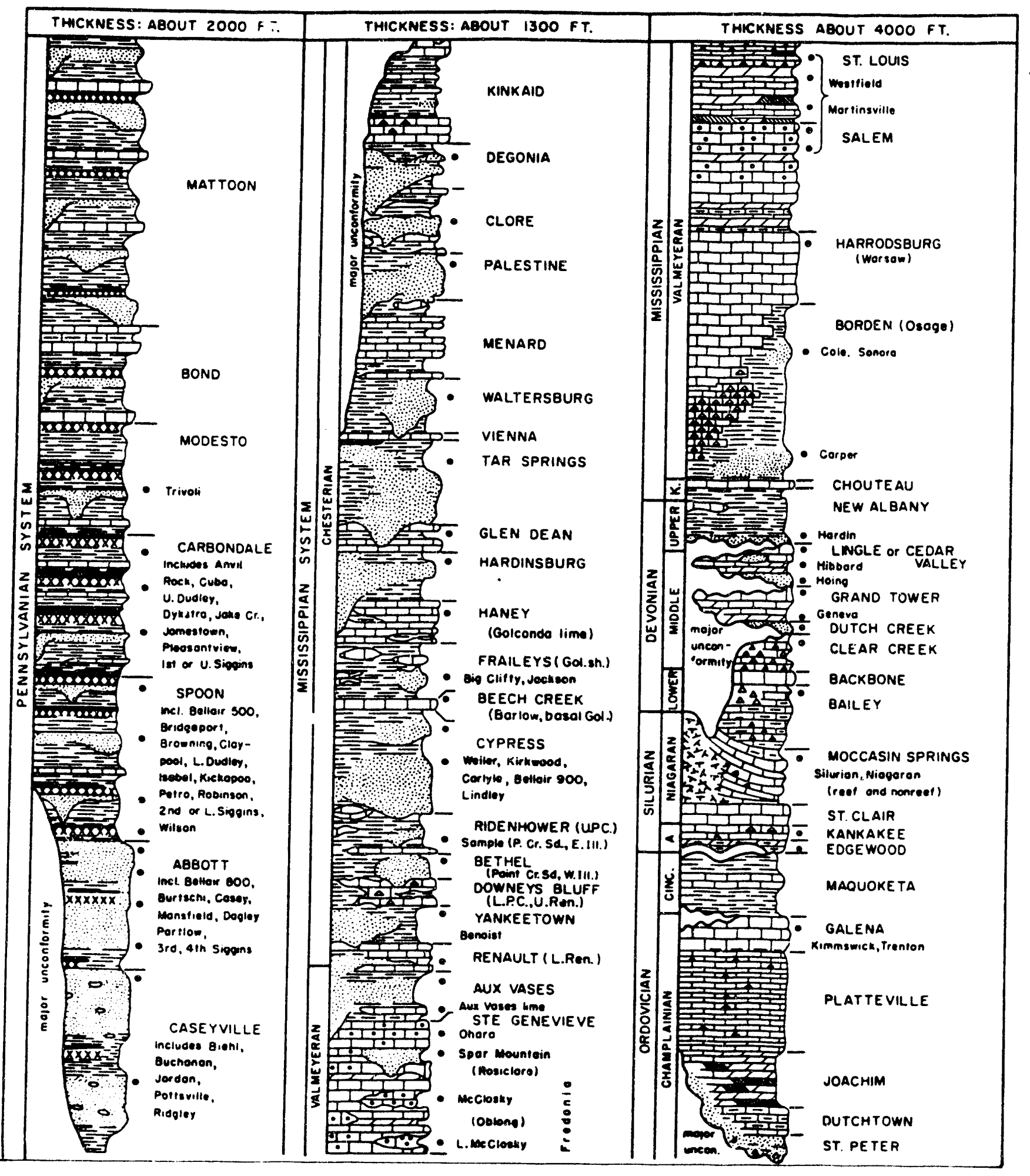

FIGURE 19. - Stratigraphlc column of the Illinols Basin. Lower non-producing units of the Paleozolc are not illustrated. Dots Indicate oll and gas intervals. Afser Landes, 1970; Swana, 1968. 
The Illinois Basin is highly productive from Mississippian and Pennsylvanian Age sediments (Bally, 1980). During the Kaskaskia Sequence (Upper Ordovician through Mississippian), the Illinois Basin received tidal influences, whereas the Michigan Basin, to the northwest, was isolated (Leighton and Kolata, 1991; Oltz, 1991). During the Absaroka Sequence (Pennsylvania and Lower Permian), rapid accumulation of deltaic sediments occurred at the continental edge margins (Oltz,1991). Deposition within the Illinois Basin was shallow water deposits of multiple thin pay units (Oltz, 1991; Leighton and Kolata, 1991). The rate of marine deposition within the basin was two-thirds inch per thousand years (Swann, 1968; Landes, 1970). Figures 17 and 18 emphasize the shallow, gently dipping structure of the Illinois Basin. The La Salle anticline and related structural features began to form in the late Mississippian (Landes, 1970). Faults in the western Illinois Basin are shown in Fig. 20. The downwarping of the basin increased during the glaciations of the Pleistocene (Landes, 1970). Oil production is from the southern part of the Illinois Basin. Stratigraphic intervals which are productive from the Upper Ordovician to the Upper Pennsylvanian are shown in Fig. 19 (Swann, 1968; Landes, 1970).

Most oil produced from the Illinois basin is light, sweet, paraffinic oil. Two fields, Carlinville North and Omaha, in southern Illinois produce heavy oil of $19^{\circ} \mathrm{API}$ and $20^{\circ} \mathrm{API}$ from Pennsylvanian sediments (Crysdale and Schenk, 1990). Carlinville North produces from the Pottsville, a consolidated sandy conglomerate with average porosity of $18 \%$, average permeability of $100 \mathrm{mD}$, and a net pay zone of $10 \mathrm{ft}$ (Crysdale and Schenk, 1990). Omaha Field produces heavy oil from an unnamed Pennsylvanian consolidated sandstone stratigraphically somewhat above the Pottsville. The net pay thickness is $10 \mathrm{ft}$ with an average porosity of $19 \%$ and average permeability of $100 \mathrm{mD}$. Production of heavy oil ( $\left.19^{\circ} \mathrm{API}\right)$ from Omaha Field has been less than 10,000 bbl (Howard, 1991).

In the early to mid 1980s, exploratory drilling on the eastern margin of the Illinois Basin in Indiana and Kentucky was expanded (Gilbert, et al., 1985). These wells produce mainly light oils (Gilbert et al., 1985). Most production was from the Mississippian Age Harrodsburg, Aux Vases, Cypress and Saint Genevieve Formations in Indiana and from the Mississippian Aux Vases and Big Lime and Devonian Clear Creek Formations in Kentucky (Gilbert et al., 1985; Oltz, 1991). Production from the Big Lime Formation in Kentucky was gas (Gilbert et al., 1985).

\section{Michigan Basin}

The Michigan Basin is one of several intercratonic basins found in the northern United States (Leighton and Kolata, 1991). Illinois and Williston basins (North and South Dakota and Canada) are comparable in size and depositional characteristics. Geographically, the Michigan basin occupies the entire upper peninsula of Michigan, eastern Wisconsin, and corners of northern 


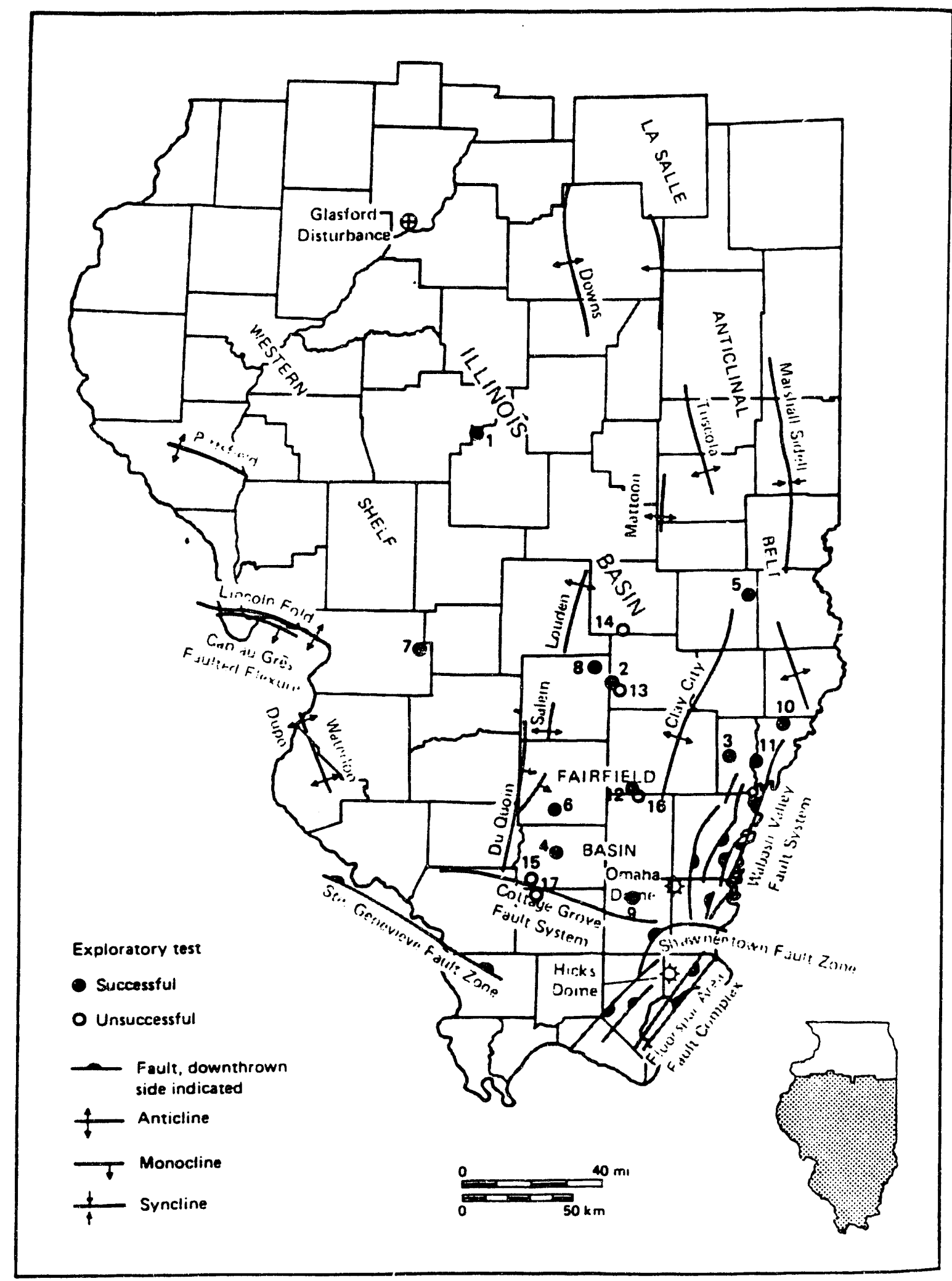

FGGURE 20. - A structure map of the western two-thirds of the Illinols Basin. Contour interval is $500 \mathrm{fl}$. After Gllbert et al.,1985. 
Illinois and Indiana and extends into Lake Superior and southern Ontario and Lake Huron (Fig. 21) (Cohee and Landes, 1958; Landes, 1970). Structurally, the circular basin is bounded on the north by Precambrian crystalline basement rocks (Fig. 22) (Landes, 1970), on the west by the Wisconsin Arch, on the south by the Kankakee Arch, and by the Finlay Arch on the east (Cohee and Lanes, 1958) (Fig. 21). Stratigraphically, hydrocarbons are found in Paleozoic rocks from Ordovician to Pennsylvanian Age with 95\% of the oil produced from Devonian Age rocks (Cohee and Landes, 1958).

Oil is found in older Ordovician rocks of the Black River and Trenton limestones (Fig. 23). This area of southern Michigan and Ontario produces oil and gas from crystalline limestones and dolomites (Cohee and Landes, 1958).

Drilling in the Michigan Basin from 1968 to 1987 was dominated by exploration and development of Middle Silurian Niagaran reefs. These wells produced predominantly light oil from $30^{\circ}$ to $60^{\circ}$ API (Bricker and Henderson, 1985). Secondary targets were mainly in Devonian Detroit River sour zone and Richfield zone (Fig. 23) (Bricker and Henderson, 1985).

Silurian Age rocks produce the only heavy oil found in the Michigan Basin (Crysdale and Schenk, 1990). The Salina Formation produces some heavy oil from four fields in southern Michigan: Dorr and Hopkins West fields in Allegan County, Pennfield Field in Calhoun County and Zeeland Field in Ottawa County (Crysdale and Schenk, 1990). Lithologically, the heavy oil is produced from dolomites and has a gravity of $17^{\circ}$ to $20^{\circ}$ API. To date, Dorr Field has produced over 350,000 bbl of heavy oil. The net pay zones in Dorr, Hopkins West, and Zeeland fields average only 5 to $7 \mathrm{ft}$ thick, and in Pennfield, $113 \mathrm{ft}$ thick (Crysdale and Schenk, 1990). The fields presently worked are small, but there is the potential for more heavy oil discoveries in Silurian Age dolomites.

Hydrocarbons in the Michigan Basin are concentrated in the limestones and dolomites of Middle Devonian Age in the central part of the basin (Cohee and Landes, 1958). The Detroit River Group of Middle Devonian Age produces light oils from evaporite rocks in the center of the Michigan Basin at depths of 1,000 to 2,000 ft (Cohee and Landes, 1958). Pay zones in the dolomitic Lucas Formation of the Detroit River Group (Fig. 23) range from 100 to $200 \mathrm{ft}$ thick (Landes, 1970; Cohee and Landes, 1958).

In 1988, the exploration and development on the Michigan Basin shifted to Devonian Antrim shale and Ordovician Prairie du Chien dolomites (Briker and Henderson, 1989). The wells drilled in the Prairie du Chien were classed as gas plays (Bricker and Henderson, 1989). The Silurian Niagaran reefs bordering the northern portion of the Michigan Basin are seen as the area for development in the 1990s. Oil gravity in the Niagaran and Prairie du Chien Formations ranges from low $60^{\circ}$ to mid-70 $\mathrm{API}$ (Brinker and Henderson, 1989). 


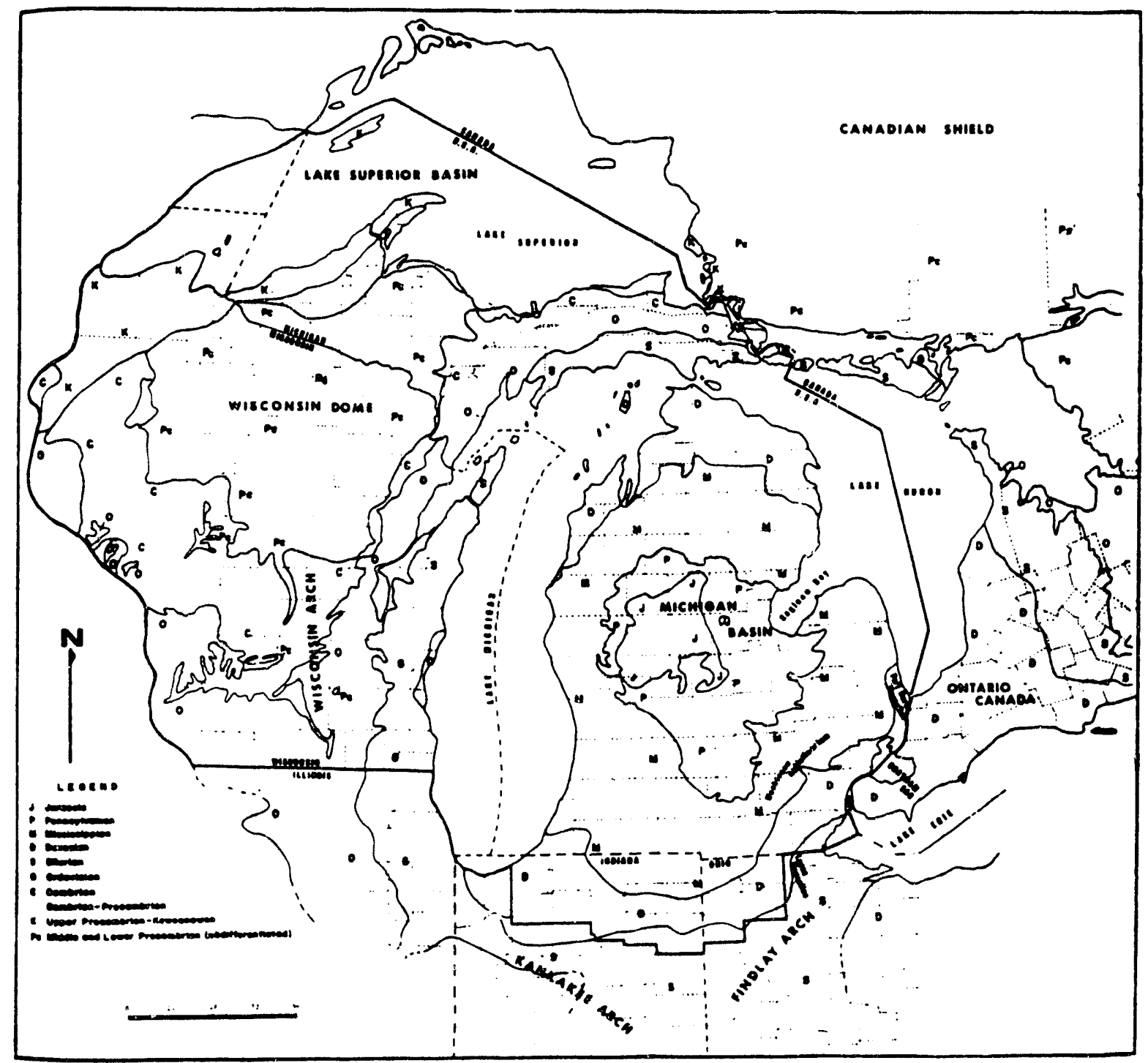

FTGURE 21. - The Michigan Basin showing the distribution of Paleozolc rock units and the structure of the rezion. After Cram, 1971. 


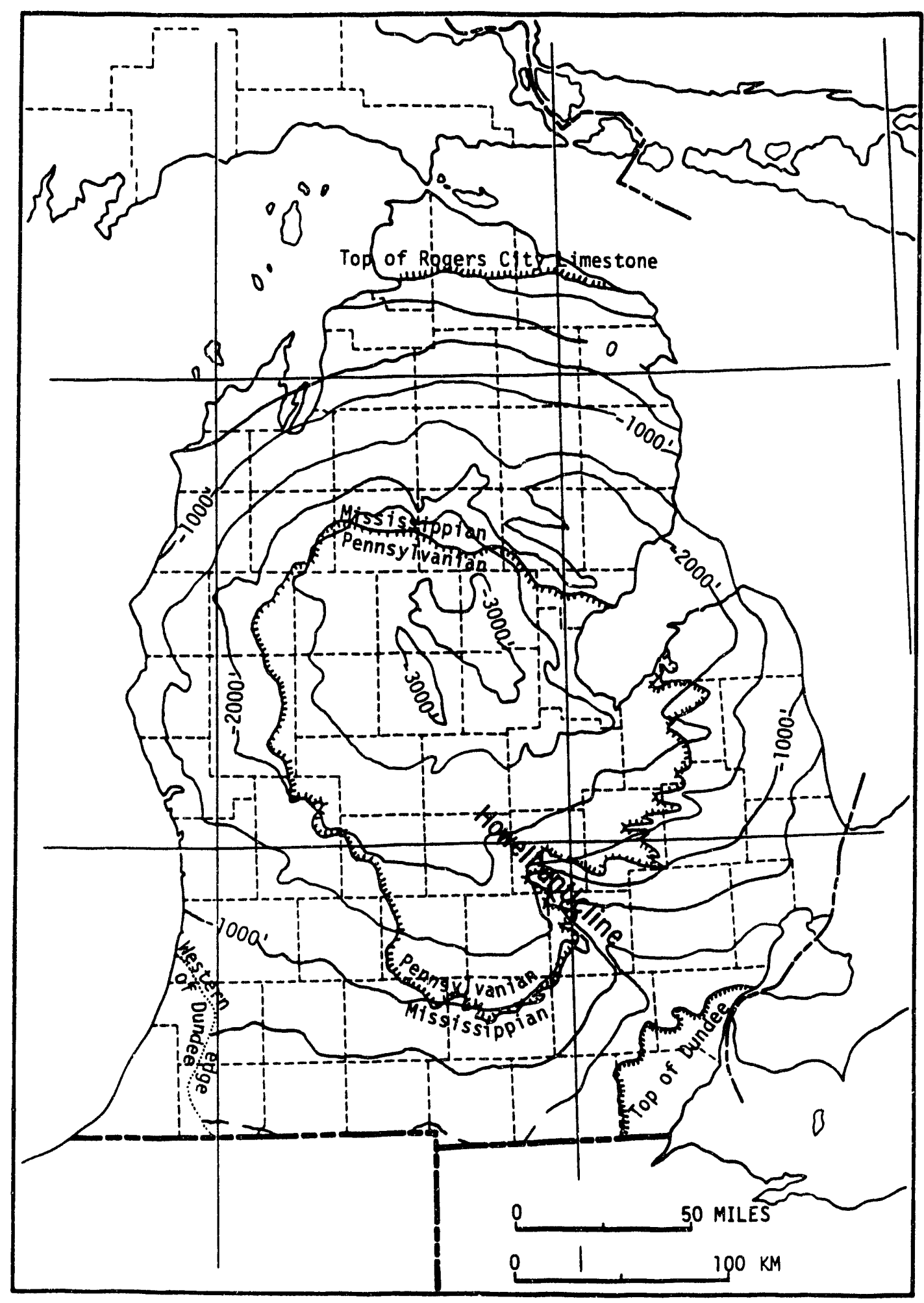

FIGURE 22. - A structure map of the maln portion of the Michigan Basin. Contour Interval is $590 \mathrm{n}$. After Landea, 1970; Cohee, 1948. 


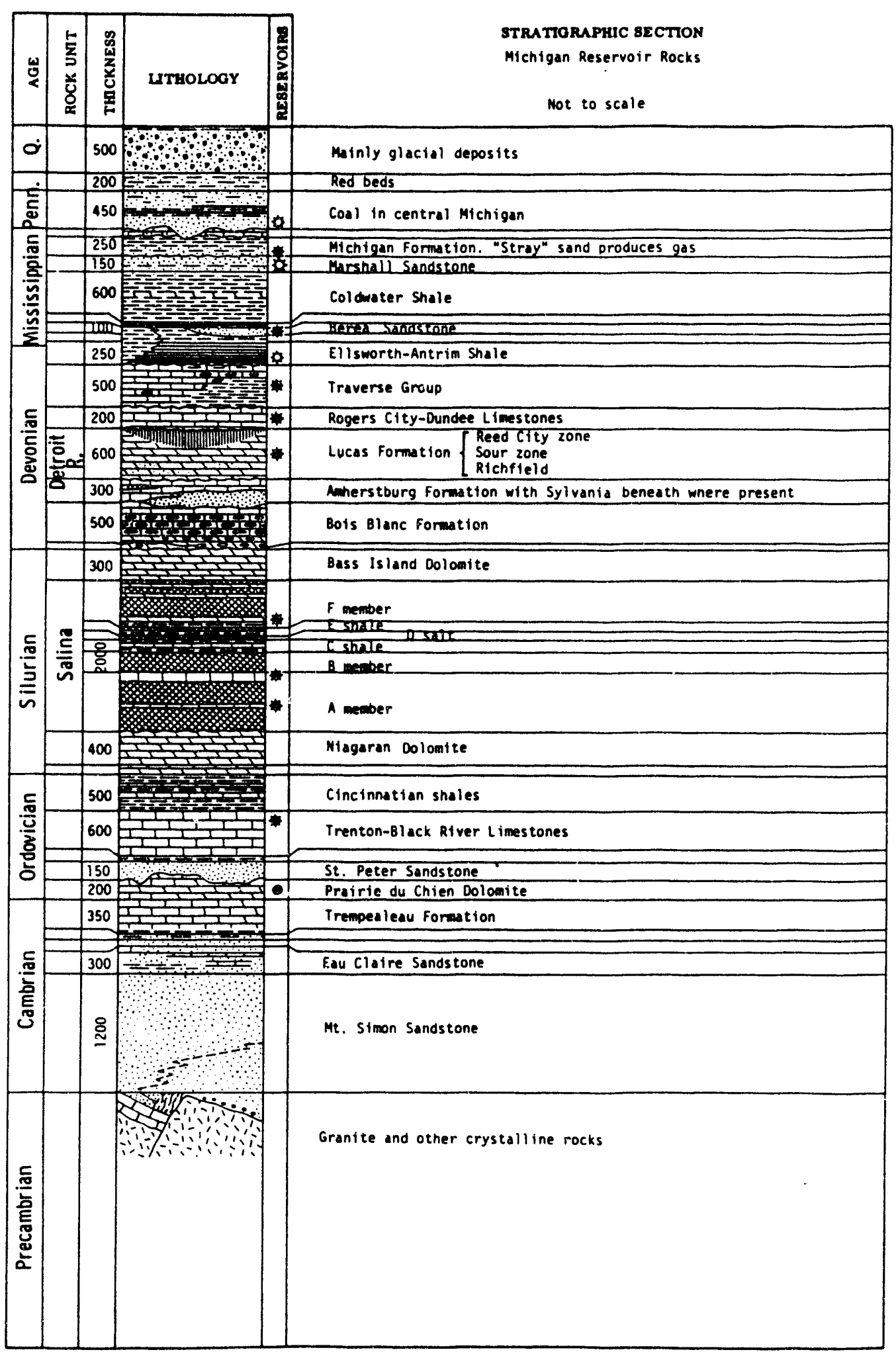

FIGURE 23. - The stratigraphic column of the Michlgax Basin showing the oll and gas reservolrs. After Landes, 1970; Michigan Geological Survey, 1964. 
Shallow wells in Mississippi Age Brea sandstones and Pennsylvania Age Parna sandstones have produced some light oils and gas, but these are not highly productive areas in the Michigan Basin (Cohee and Landes, 1958). Any future exploration for heavy oils in the Michigan Basin will concentrate on the Silurian Age rocks on the southwestern edge of the basin. Discovery of heavy oils to date does not suggest any major deposits in the Michigan Basin.

\section{CONSTRAINTS}

Heavy oil is successfully being produced by cyclic steam, steamflood and in situ combustion from principally unconsolidated or friable reservoirs in California, Canada, Indonesia, and Venezuela. In the United States, TEOR is the largest enhanced oil producing technology contributing $69 \%$ or 454,000 BOPD of the 656,700 BOPD total U.S. EOR production (Moritis, 1990). The consolidated nature of the heavy oil-bearing formations in the Appalachian, Black Warrior, Illinois, and Michigan Basins limits economic production because of the low porosity and permeability as well as the thin pay zones. The oils in these basins are principally paraffinic, unlike the asphaltic California heavy crudes, and thus command a higher price than asphaltic oils of the same gravity.

\section{Refining and Transportation}

The crude oil transportation network in the Appalachian, Black Warrior, Illinois, and Michigan Basins are dominated by collection lines for paraffinic light oil and by major interstate lines carrying crude oil to major refineries (Fig. 24). In states surrounding and within these basins, a significant volume of imported oil is refined. The Petroleum Administration for Defense Districts, PADDs, are shown in Fig. 25. The East Coast, which now relies $95 \%$ on imported crude oils, has the second heaviest, high-sulfur stream of U.S. refining regions (Figs. 26-27, Olsen and Ramzel, refining, 1991). Only California in PADD 5 refines heavier, higher sulfur crude oil. The refineries at Minneapolis and St. Paul, Minnesota rely heavily on Canadian crude oils, and although much of it is inported as $20^{\circ}$ to $25^{\circ}$ API gravity, the composition is a light diluent and heavy oil or bitumen or upgraded bitumen. The refineries near Chicago import not only heavy crudes (with diluent added) from Canada, but also heavy crude from Venezuela and other countries. Major heavy oil refineries include the Amoco oil refinery in Whiting, Indiana; the Chevron refinery in Pert Amboy, New Jersey; and the Star Enterprise refinery in Delaware City, Delaware. These refineries process significant volumes of heavy oil and large volumes of $20^{\circ}$ to $25^{\circ}$ API gravity imported crudes (American Petroleum Institute, monthly crude oil and petroleum products listing, 1991). The Midwest has the second lightest, low sulfur throughput at present, but it is moving steadily toward heavier, higher sulfur feeds. This region imported $37 \%$ of its oil in 1990, versus only $20 \% 10$ years ago (Benedict, 1991) 


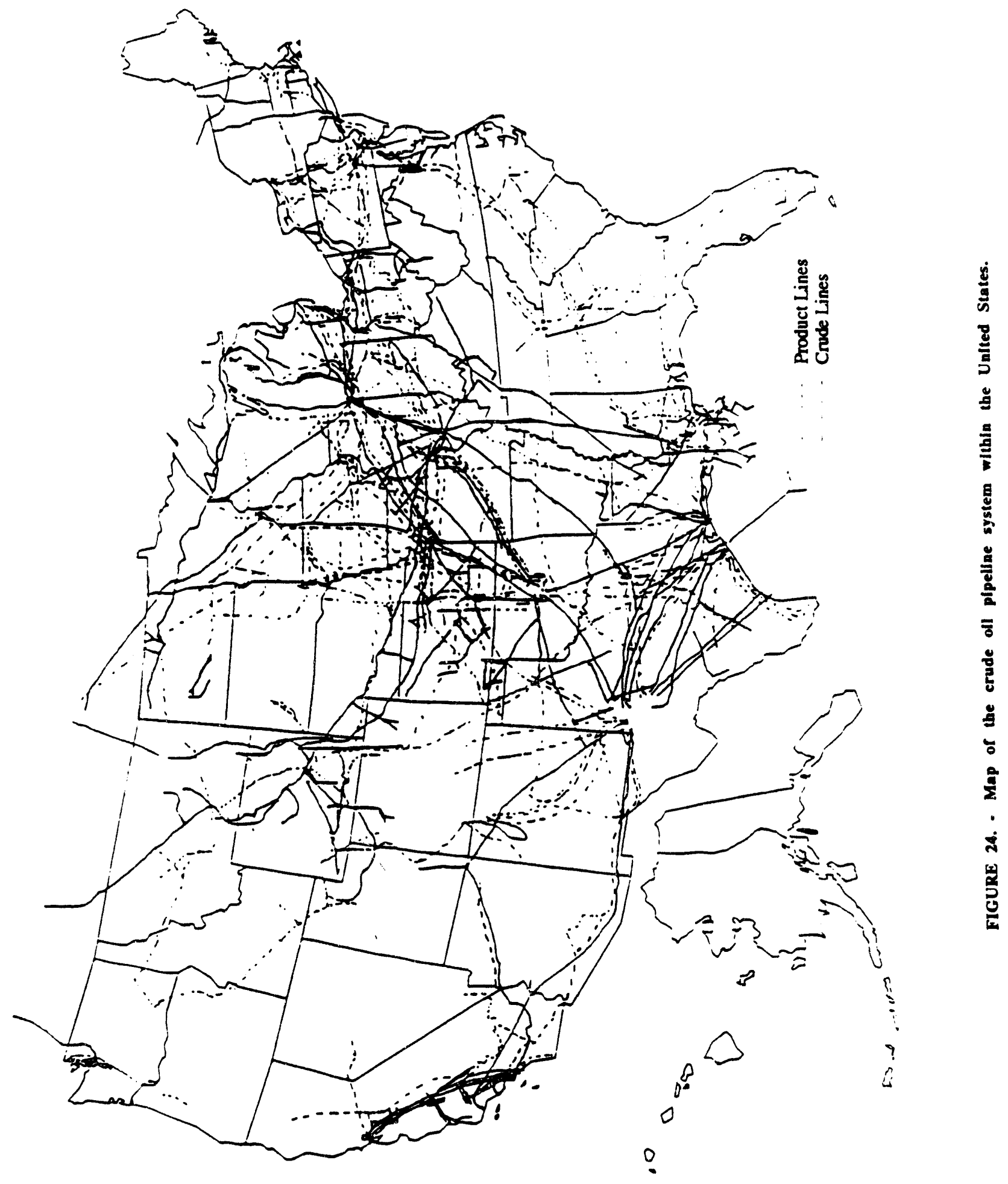




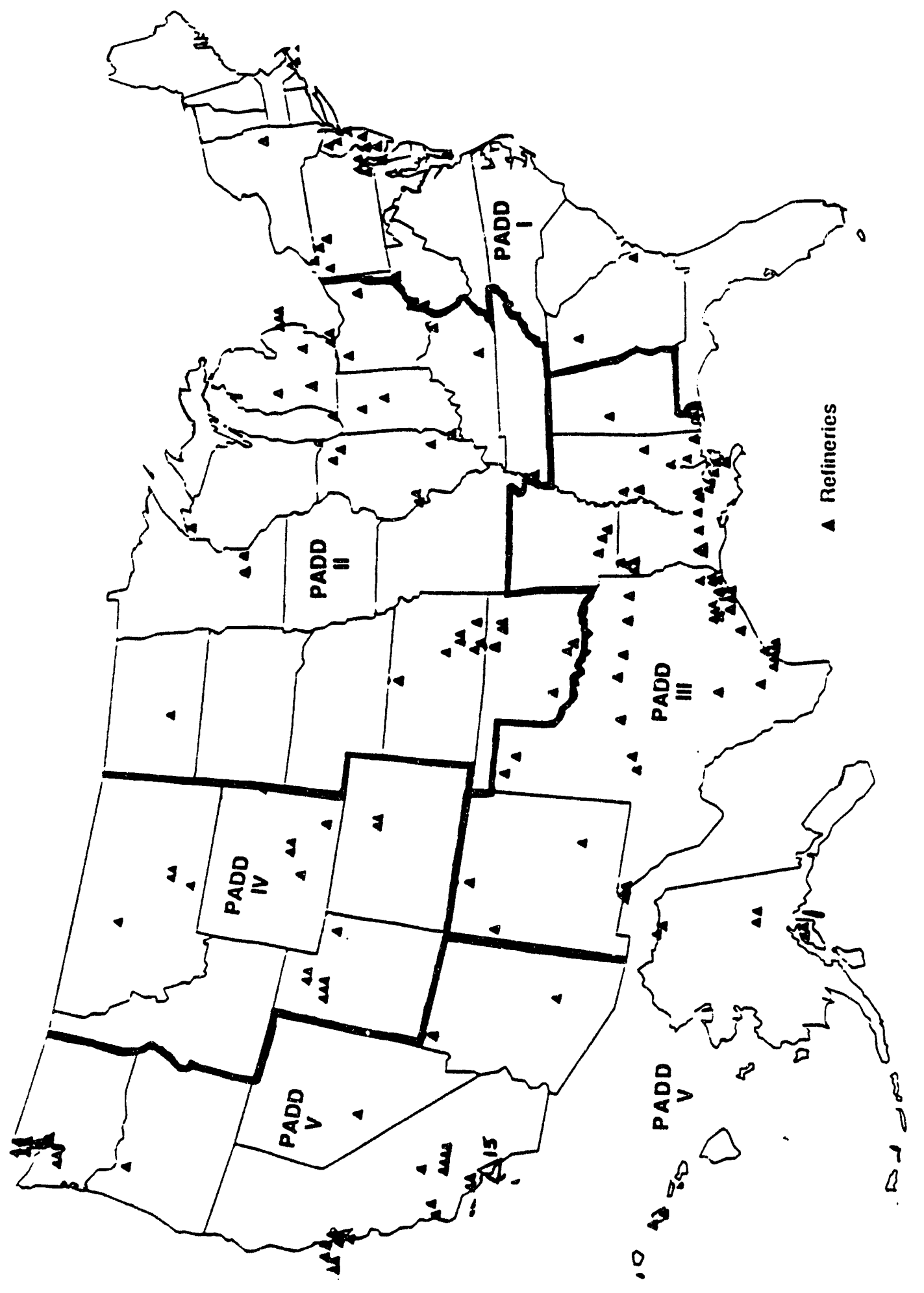

을 


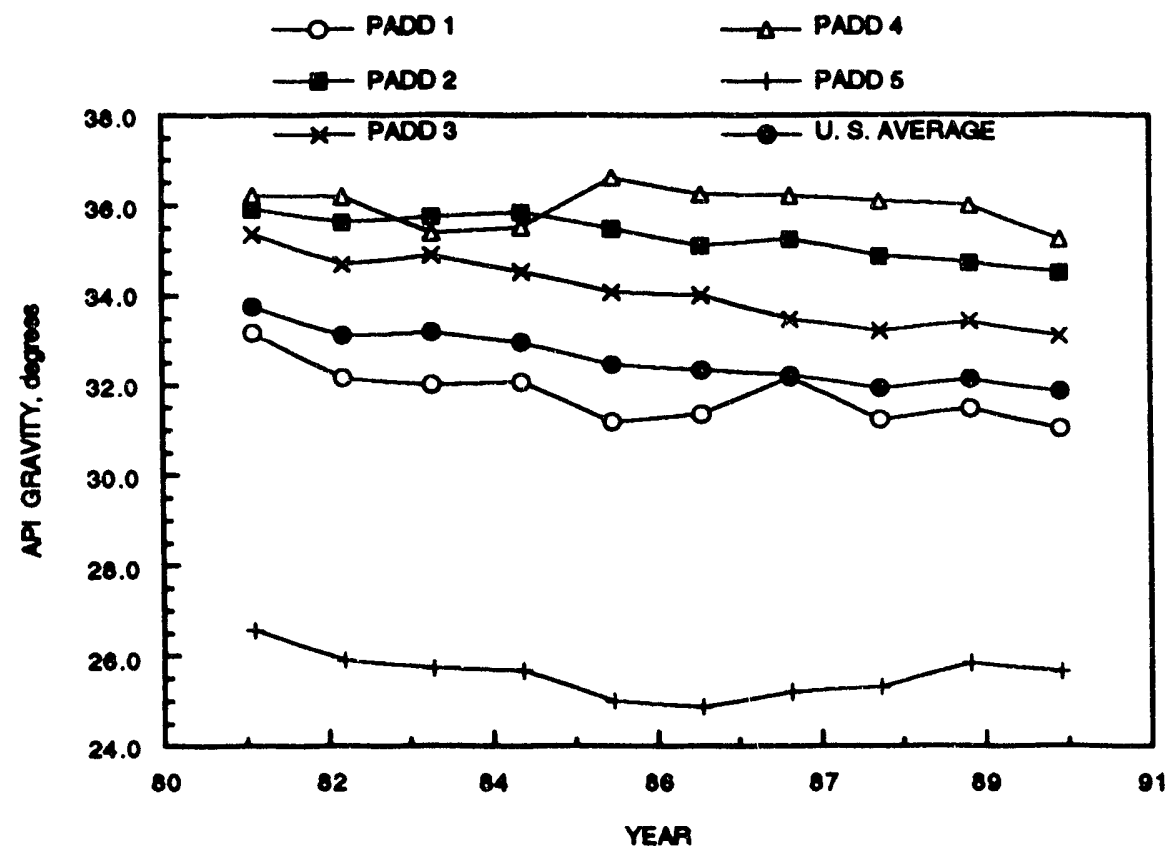

FIGURE 26. - Treads in API gravity of refinery feed within each PADD In the United States.

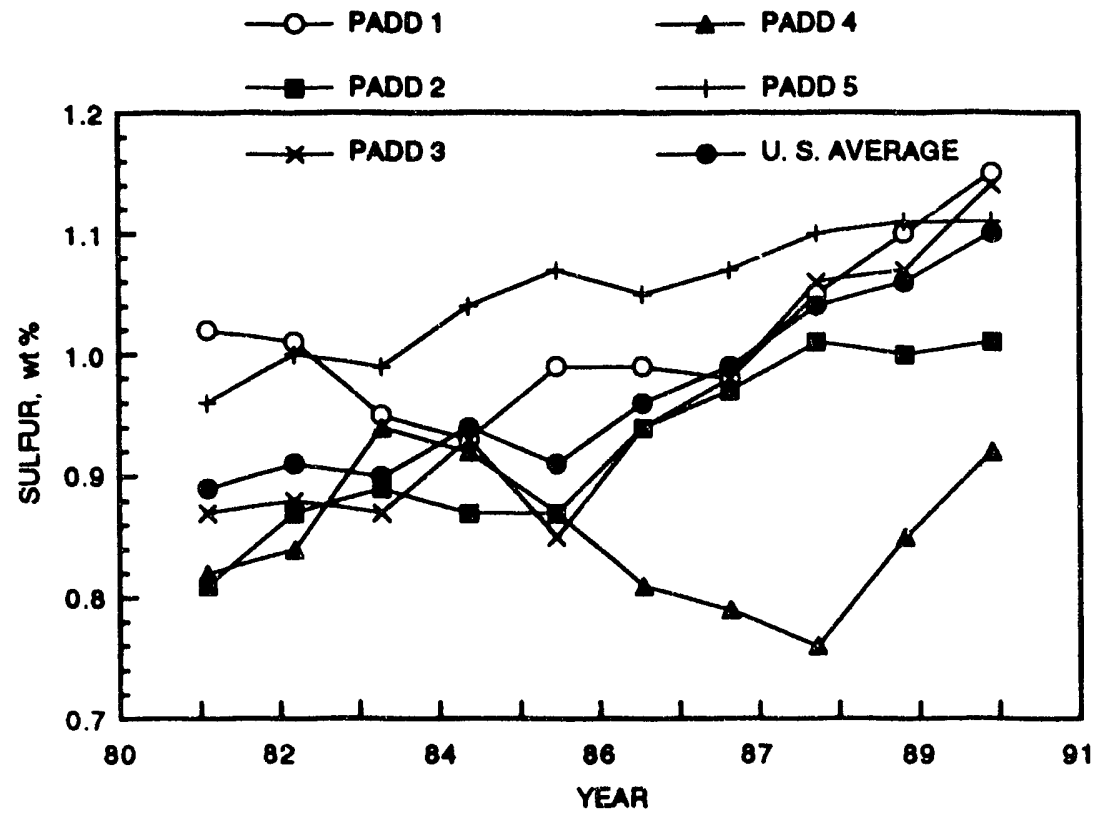

FIGURE 27. - Treads in suifur content of refinery feed within each PADD in the United States. 
The basins contain extensive infrastructures to support primary production and aging, rapidly declining waterfloods to recover light oil. The light oil in these basins has become more sour due to waterflooding that has supported this region for the past 40 years. Most of the refineries in these basins are designed to process light crude oils, and addition of heavy oil would significantly impact operation since they have limited capability to process heavy ends (Thrash, 1990: Thrash, 1991). Only those large, essentially dedicated refineries currently processing foreign heavier crude oil or those with large coking capacity would be available to process any domestic heavy oil should it become available from other areas. A separate heavy oil gathering system with heated pipelines to transport oil to suitable refineries would require much larger production and better refining economics to be justified, and this is not anticipated.

\section{Environmental}

The Appalachian, Black Warrior, Illinois, and Michigan Basins typify the U.S. oil patch. Oil is a major industry only in specific communities. Increasing awareness of the environment is becoming incorporated into the petroleum industry's mode of doing business. Since the level of anticipated thermal oil recovery operations to produce heavy oil will be minimal for the near future, water and air quality will not be significantly impacted. As the 1990 Clean Air Act mandates cleaner gasoline and diesel fuels, refineries in the North East will have a significantly harder time to transform both domestic and imported crudes into cleaner fuels. The trend of feed to these refineries has been towards higher sulfur and lower API gravity crudes (Olsen and Ramzel, 1991).

\section{Economics of Thermal Heavy Oil Production}

The economics of heavy oil recovery in the Appalachian, Black Warrior, Illinois and Michigan Basins was not analyzed because of the small resource. The 1990 costs of thermal operations are reprinted as obtained from the assessed evaluation of thermal (steam) operations in Kern County, California (Maples, 1990, Table 1, the cost of drilling and completing thermal wells, and Table 2, yearly operating cost). Operators produce heavy oil on primary, even stripper production, or by waterflooding of deeper reservoirs and produce paraffinic based heavy crude oil. Because heavy oil is more viscous than light oil, the mobility ratios will be adverse to water. Operators waterflooding reservoirs with heavy oil are probably at a lower oil to water ratio than those waterflooding light oils, and their operating costs would be higher per barrel of oil produced. For the shallow heavy oil operator, their production per well is usually classified as stripper wells ( $<10$ BOPD), and most are producing between 0.25 and 2 BOPD. Since the operators continue to operate, these wells were deemed marginally economical. The volume of oil produced is small and

the recovery efficiency is probably less than 5\%. The royalties and tax liabilities within the middle United States are listed in Table 3. 


\section{CONCLUSIONS}

The Appalachian, Black Warrior, Illinois, and Michigan Basins are minor heavy oil producing basins, and they do not seem destined to increase their role in supplying significant heavy oil to the United States. Little of the heavy oil will be produced by TEOR. Thermal methods to produce the low pour point paraffinic oil from reservoirs in these Basins are potentially economic because paraffinic oil brings a premium price. Limitations to the development of low pour point oils include the lack of knowledge of the extent of the resource and ownership by small independent operators who do not have capital or experience in thermal oil recovery.

\section{ACKNOWLEDGMENTS}

This work was sponsored by the U.S. Department of Energy under cooperative agreement DE-FC22-83FE60149 as project SGP37. The anthors thank W. I. Johnson, M. K. Tham and A. Strycker of NIPER, and T. B. Reid of the DOE Bartlesville Project Office for their critical reviews. The authors wish to thank the staff of the geologic surveys of Alabama, Illinois, Indiana, Kentucky, Michigan, Mississippi, New York, Pennsylvania, Ohio, Tennessee, and West Virginia and the U.S. Geological Survey; and the regulatory agencies of these states for their cooperation in defining the potential of heavy oil recovery in the Appalachian, Black Warrior, Illinois, and Michigan Basins.

TABLE 1. - Cost of drilling and completing thermal EOR wells (Maples, 1990-91)

\begin{tabular}{rrr}
\hline Weil depth. It & \multicolumn{3}{c}{ NEW PRODUCING WELL COSTS } \\
\cline { 2 - 3 } $0-250$ & 37,000 & \\
$251-750$ & 73,000 & 30,000 \\
$751-1,250$ & 89,000 & 60,000 \\
$1,251-1,750$ & 121,000 & 100,000 \\
$1,751-2,250$ & 160,000 & \\
$2,251-2,750$ & 200,000 & \\
$2,751-3,250$ & 240,000 & \\
\hline
\end{tabular}

TABLE 2. - Yearly thermal steam operating cost -anges within each field/well (Maples, 1990-91)

\begin{tabular}{lcc}
\hline Field & Cyclic steam. S & Steamfload. $S$ \\
\hline Cymric & 20,000 & 27,500 \\
Kern River & 20,000 & 27,000 \\
Midway-Sunset & 18,000 & 26,000 \\
\hline \multicolumn{3}{c}{ Steam generator maintenance cosis/BTU barrel equivalent of oil burned, in $\$$} \\
Gas fired $=0.10$ & Oilfired $=0.20$ \\
\hline
\end{tabular}


TABLE 3 - Comparisons of economic factors affecting oil production from middle U.S.

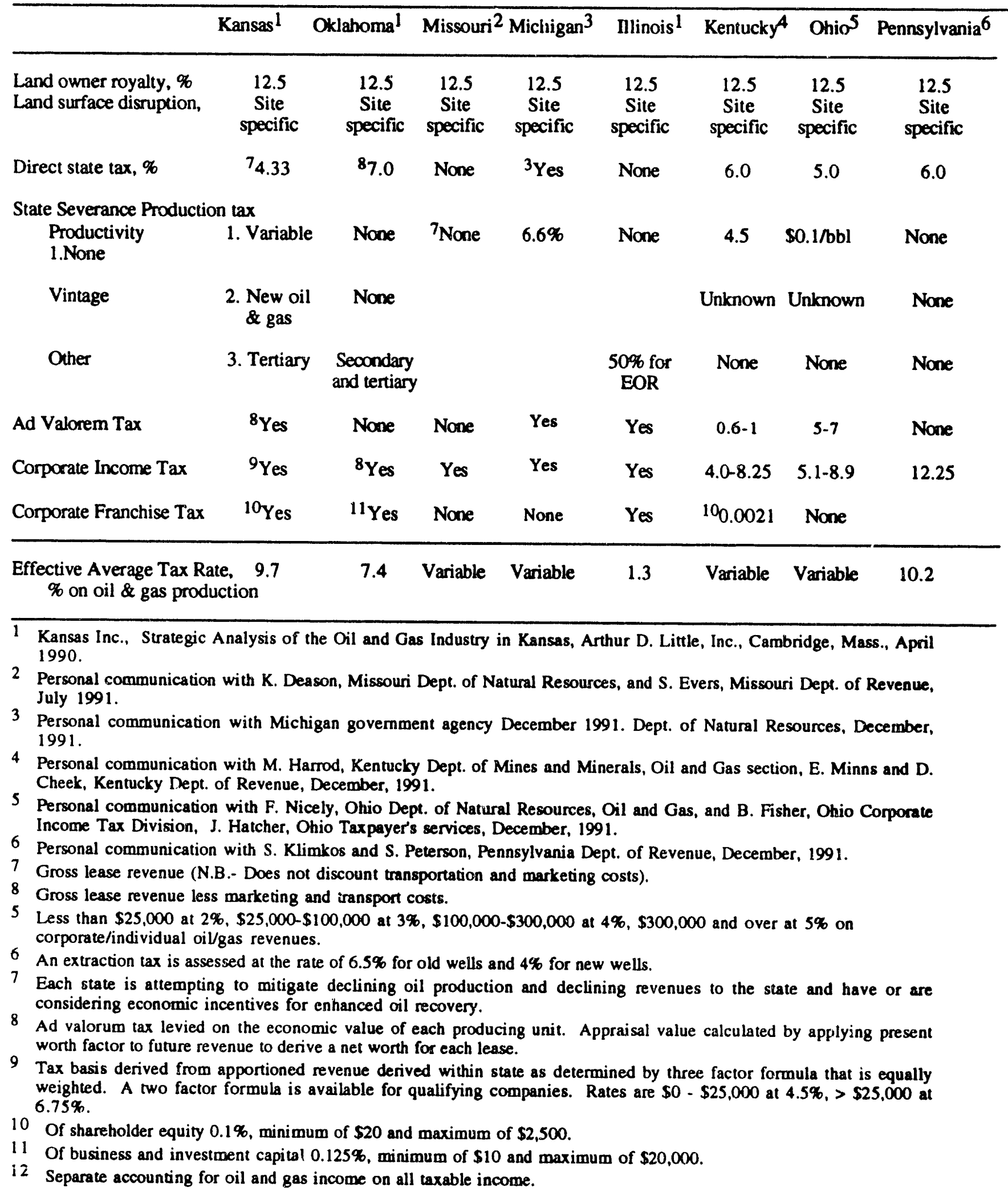




\section{BIBLIOGRAPHY}

American Petroleum Institute: Monthly Crude Oil and Petroleum Products listing, published monthly by the American Petroleum Institute finance, Accounting and Statistics Department, Washington, D.C. Based on data collected by the Office of Oil Imports of the U.S. Dept. of Energy pursuant to the provisions of Public Laws 93-275 and 93-159.

Arkle, T. Jr.: Stratigraphy of the Pennsylvanian and Permian Systems of the Central Appalachians. Briggs, G. Ed., Carboniferous Systems of the Southeastern United States. Geol. Soc. America Spec. Paper 148, 1974, pp. 5-29.

Bally, A. W.: Basins and subsidence -- A Summary. in, Bally, A. W., Bender, P. L., McGetchin, T. R., and Walcott, R. I. eds., Dynamics of plate interiors, American Geophy. Union and Geological Society America, Geodynamic Series, v.1, 1980. pp.5-20.

Bayer, K. C.: Map showing approximate eastern limit of commercial oil and gas fields in relation to structural features and physiographic provinces in the Appalachian Region. U. S. Geological Survey, Chart OC 121, 1982.

Bayles, R. E.: Wood County Deep Well: log, sample and core description. West Virginia Geological Survey, Rept. Inv. 14, IV, 1956.

Beardsen, B. L.: Petroleum trapping mechanisms in the Carter sandstone (Upper Mississippian) in the Black Warrior Basin of Alabama. Alabama Oil and Gas Board, Oil and Gas Report 9, 1985,50 p.

Becker, L. E. and S. J. Keller: Silurian Reefs in Southwestern Indiana and their relation to Petroleum Accumulations. Indiana Geological Survey, v.19, Bloomington, In, 1976, 11 p.

Benedict, R.: Shift to Higher Sulfur Oil Senn in All Refining Regions, Oil Daily, Sept 17, 1991.

Bond, D. C., A. Elwood, H. M. Bristol, T. C. Buschbach, D. L. Stevenson, L. E. Becker, T. A. Dawson, E. C. Fernalld, H. Schwealb, E. N. Wilson, A. T. Statler, R. G. Stearns, and J. H. Buehner: Possible Future Petroleum Potential of Region 9 - Illinois Basin, Cincinnati Arch, and Northern Mississippi Embayment. in Future Petroleum Provinces of the United States-- Their Geology and Potential, I. H. Cram, ed., AAPG, 1971, pp. 1165-1218.

Bricker, D. M. and W. L. Henderson: Oil and Gas Developments in Michigan in 1984. AAPG Bull. 69 (10), 1985, pp. 1543-1547.

Bricker, D. M. and W. L. Henderson: Oil and Gas Developments in Michigan in 1988. AAPG Bull. 73 (10B), 1989, pp. 81-86.

Clark, L.: Personal Communication, Independent Oil Producers' Agency, Taft, California, November 1991.

Cohee, G. V.: Thickness and lithology of Upper Ordovician and Lower and Middle Silurian rocks in the Michigan Basin. U. S. Geol. Sur. Oil and Gas Inv. Prelim. Chart 33, 1948.

Cohee, G. V. and K. K. Landes: Oil in the Michigan Basin. in. Weeks, L. G., ed., Habitat of Oil. AAPG, 1958, p. 473-493. 
Combs, E. J.: Summary of future petroleum potential of Region 8, Michigan Basin. in, Cram, I. H. ed., Future Petroleum Provinces of the United States--Their Geology and Potential. AAPG, 1971, pp. 1121-1123.

Cram, I. H.: Future Petroleum Provinces of the United States - Their Geology and Potential, AAPG Memoir 15, American Association of Petroleum Geologist, Tulsa, OK. 1971.

Crysdale, B. L. and C. J. Schenk: Heavy Oil Resources of the United States, US Geological Survey Bulletin 1885, U.S. Geological Survey, 1990.

DeWitt, W. Jr. and R. C. Milici: Energy resources of the Appalachian Orogeny. in, Hatcher, R. D. Jr., Thomas, W. A. and Viele, G. W., eds. The Geology of North America, V. F-2 The Appalachian-Ouachita Orogeny in the United States. Geol. Soc. America, 1989, p. 495-510.

DeWitt, W., Jr. and L. W. McGrew: Appalachian Basin Region, in Craig, L.C. and C.W. Connor, eds., Paleotectonic investigations of the Mississippian System in the United States: U.S. Geological Survey Professional Paper 1010-C, 1979, p. 41.

DeWitt, W., Jr., W. J. Jr. Perry, and L.G. Wallace: Oil and gas data from Devonian and Silurian rocks in the Appalachian basin: U.S. Geological Survisy Miscellaneous Investigation Series Map I-917B, scale 1:2,500,000, 1975.

Dietzman, W. D., M. Carreles, and C. J. Jirik: Heavy Crude Oil Reservoirs in the United States: U.S. Bureau of Mines Information Circular 8263, 1966, p. 53.

Droste, J. B. and R. H. Shaver: Upper Silurian and Lower Devonian stratigraphy of the Central Illinois Basin. Indiana Geol. Sur., v.39, Bloomington, In, 1987, 29 p.

Ells, G. D.: Future Oil and Gas possibilities in Michigan Basin. in, Cram, I. H. ed., Future Petroleum Provinces of the United States--Their Geology and Potential, AAPG, 1971, p.1124-1162.

Englund, K. J.: Sandstone Distribution Patterns in the Pocahontas Formation of Southwest Virginia and Southern West Virginia. in, Briggs, G. ed., Carboniferous of the southeastern United States, Geol. Soc. America Spec. Paper 148, 1974, pp. 31-45.

Epsman, M. L.: Subsurface Geology of Selected Oil and Gas fields in the Black Warrior Basin of Alabama, Geological Survey of Alabama, Atlas 21, 1987, 255 p.

Gilbert, R. C., G. L.Carpenter, F. H. Walker, and J. Van Den Berg: Oil and Gas Developments in East-Central States in 1984. AAPG Bull. 69 (10), 1985, pp. 1534-1542.

Gill, D.: Kern County, Oil \& Gas Investor, August 1990, pp. 14-27.

Group of Experts: UNITAR Proposal for the Definition of Heavy Crude and Tar Sands and Addendum, Second International Conference on Heavy Oil and Tar Sands, Caracas, Venezuela, February 1981.

Halvatzis, G. J.: Oil and Gas Developments in Southeastern States in 1984. AAPG. Bull. 69 (10), 1985, pp. 1622-1626.

Halvatzis, G. J.: Oil and Gas Developments in Southeastern States in 1988. AAPG Bull. 73 (10B), 1989, pp. 136-140. 
Harris, A. G., L. D. Harris, and J. B. Epstein: Oil and gas data from Paleozoic rocks in the Appalachian basin: Maps for assessing hydrocarbon potential and thermal maturity (conodont color alteration isograds and overburden isopachs): U.S. Geological Survey Miscellaneous Investigations Series Map I-917E, scale 1:2,500,000, 1978.

Howard, D.: Illinois Geological Survey, personal communication, Dec. 18, 1991.

Ingham, A. I.: Future Petroleum Potential of Region 10-Appalachians. in Future Petroleum Provinces of the United States--Their Geology and Potential, I. H. Cram, ed., AAPG, 1971, pp. 1219-1231.

Jewell, J. W.: An Oil and Gas Evaluation of North Alabama. Geological Survey of Alabama, Bull. 93, 1969, 65 p.

Kansas Inc.: Strategic Analysis of the Oil and Gas Industry in Kansas, Arthur D. Little, Inc., Cambridge, Mass., April 1990.

Landes, K. K.: Petroleum Geology of the United States. Wiley-Interscience, John Wiley \& Suns, 1970, $571 \mathrm{p}$.

Leighton, M. W. and D. R. Kolata: Selected Interior Cratonic Basins and Their Place in the Scheme of Global Tectonics: a synthesis. in Interior Cratonic Basins, Leighton, $M$. W., Kolata, D. R., Oltz, D. F., and Eidel, J. J. eds., AAPG Memoir (World Petroleum Basins), Tulsa, Ok, 1991.

Leonard, J.: Increased Rate of EOR Brightens Outlook, Oil \& Gas Journal: Production/Enhanced Recovery Report, April 14, 1986, pp. 71-101.

Leonard, J.: Steam Dominates Enhanced Oil Recovery, Oil \& Gas Journal: Annual Production Report, v. 80, April 5, 1986, pp. 139-159.

Maples, J. W.: Crude Oil Prices 1991, Kern County Assessor, Oil and Gas Properties Division, Kern County, California, February 1991.

Maples, J. W.: Oil and Gas Properties Appraisal Parameters, 1990-1991, Kern County Assessor, Kern County, California, March 1990.

Masingill, J. H.: The petroleum industry in Alabama, 1988. Oil and Gas Report 3-L, Geological Survey of Alabama, 1989, $100 \mathrm{p}$.

McGrain, P. and L. R. Ponsetto: Exploration for Tar Sands in Western Kentucky. Kentucky Geological Survey 1981.

Milhous, H. C.: Tennessee, key development years just ahead. World Oil, June 1960, p. 92-95.

Michigan Geological Survey: Stratigraphic succession in Michigan, Michigan Geological Survey Chart 1, 1964.

Mississippian Oil and Gas Production Annual Report 1989: Mississippi State Oil and Gas Board, 1989, pp. 35-85. 
Monin, J. C., and A. Audibert:: Alteration of Heavy Crudes Under High Pressure Steam Conditions: American Chemical Society, Division of Petroleum Chemistry, Preprints, 29(4), 1984, pp. 1223-1231.

Moritis, G.: $\mathrm{CO}_{2}$ and $\mathrm{HC}$ Injection Lead EOR Production Increase, Oil \& Gas J., Biennial EOR Survey, April 23, 1990.

Oatesan, V. N., and W. R. Shu: Alteration of Heavy Oil Characteristics During Thermal Recovery: Annual meeting of the Petroleum Society, CIM: Petroleum Society CIM Paper 4, 1984, pp. 84-35-108.

Olsen, D. K., W. I. Johnson and E. B. Ramzel: Feasibility Study of Heavy Oil Recovery in the Lower 48 States, Department of Energy Report No. NIPER-521, January 1991.

Olsen, D. K. and E. B. Ramzel: Heavy Oil Refining and Transportation: Effect on the Feasibility of Increasing Domestic Heavy Oil Production, presented at 1991 Eastern Oil Shale Symposium on Oil Shale/Tar Sands/Heavy Oil, November 13-15, 1991, Lexington, Kentucky and to be published as the proceedings of the conference in Fuel in 1991.

Oltz, D. F.: Reservoir Characterization of the Illinois Basin Including Deltaic Sands. in Opportunities To Improve Oil Productivity in Unstructured Deltaic Reservoirs, U. S. Dept. Energy Report DOE/BC-91/6/SP, January, 1991, pp.1.13-1.19.

Overby, W. K. Jr.: Generalized Geologic Column for Southern West Virginia. West Virginia Geological Survey, Chart, 1962.

Patchen, D. C., K. A. Schwarz, M. P. Mc Cormac, J. A. Harper, C. L. Cozart, W. W. Kelly, and K. L. Avary: Oil and Gas Development in Mid-Eastern States in 1988. AAPG Bull. 73 (10B), 1989, pp. 87-104

Rice, C. L.: Sandstone Units of the Lee Formation and Related Strata in Eastern Kentucky. U. S. Geological Survey Prof. Paper 1151-G, 1984', 53 p.

Rice, C. L. and J. F. Schwietering: Fluvial Deposition in the Central Appalachians During the Early Pennsylvanian. U. S. Geological Sirvey Bull. 1839, Evolution of Sedimentary Basins-Appalachian Basin, 1988, pp. B1-\$10.

Rice, C. L., E. G. Sable, G. R. Dever, Jr., and T. M. Kehn: The Mississippian and Pennsylvanian (Carboniferous) System's in the United States; Kentucky: U.S. Geological Sirvey Professional Paper 1110-F, î̄79, 32 p.

Ryder, R. T.: Stratigraphic Framework of Cambrian and Ordovician Rocks in the Central Appalachian Basin. in Appalachiarı Basin Symposium, Dept. of Interior, U. S. Geological Survey Open-File Report 88-585, 1988, pp. 6-10.

Swann, D. H.: Generalized Geologic Column of Southern Illinois. in Oil and Gas Pay Maps of Illinois Basin-A symposium, Illinois and Indiana-Kentucky Geological Society, 1968, pp. 3-20.

Thomas, G. R.: Geology of Recent Deep Drilling in Eastern Kentucky. Kentucky Geological Survey, Ser. X, Spec. Pub. 3, 1960, pp.10-28 
Thomas, W. A.: Mississippian stratigraphy of Alabama, in the Mississippian and Pennsylvanian (Carboniferous) Systems in the United States-Alabama and Mississippi: U.S. Geological Survey Professional Paper 1110-I, 1979, pp. I-1 to 22.

Thomas, W. A. and H. R. Cramer: The Mississippian and Pennsylvanian (Carboniferous) Systems in the United States-Georgia: U.S. Geological Survey Professional Paper 1110$\mathrm{H}, 1979$, pp. $\mathrm{H} 1$ to $\mathrm{H} 37$.

Thrash, L. S.: Annual Refining Survey, Oil \& Gas J., v. 89, No. 11, March 18, 1991, p. 84.

Thrash, L. S.: Annual Refining Survey, Oil \& Gas J., v. 88, No. 13, March 26, 1990, p. 77.

Wanless, H. R.: Appalachian Region. in Introduction and Regional Analysis of the Pennsylvania System: Paleotectonic Investigations of the Pennsylvanian System in the United States, McKee, E. D. and E. J. Crosby, coords., pt. 1. U. S. Geological Survey Prof. Paper 853, 1975, pp. 17-62.

Whieldon, C. E., Jr. and W. E. Eckard: West Virginia Oilfields Discovered before 1940: U.S. Bureau of Mines Bulletin, 607, 1963, 187 p.

Wilson, E. N.: Some Aspects of Drilling Activities in Eastern Kentucky. Kentucky Geological Survey, Ser. X, Spec. Pup. 15, 1968, pp. 56-63. 
APPENDIX A

TABLE A-1 


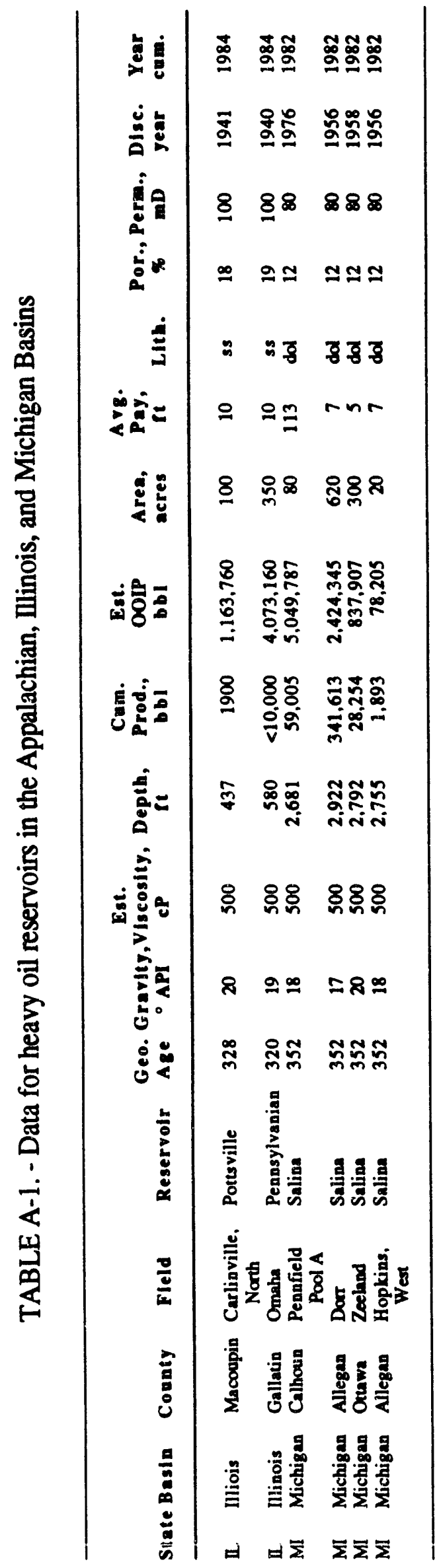

*U.S.GPO: 1992-661-026/60037 

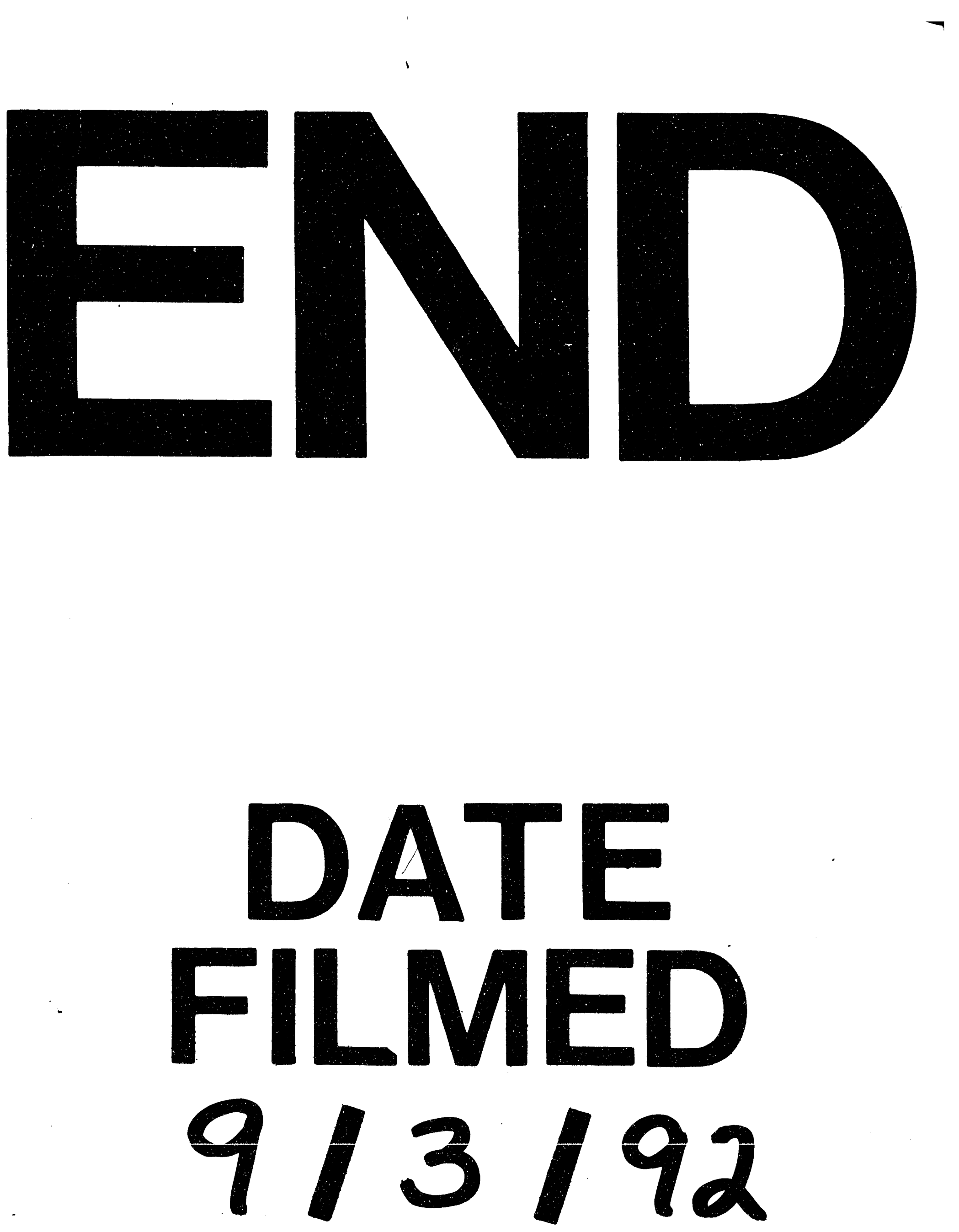

† 
